\title{
An Empirical Analysis of Substitution and Complementarity of Gender Labor Demand of Enterprises in Japan, Korea, and China: With a Factor Decomposition of Gender Wage Differentials
}

\author{
Hiromi Ishizuka \\ Sanno University, Kanagawa, Japan \\ Email: ISHIZUKA_Hiromi@mi.sanno.ac.jp
}

How to cite this paper: Ishizuka, H. (2018) An Empirical Analysis of Substitution and Complementarity of Gender Labor Demand of Enterprises in Japan, Korea, and China: With a Factor Decomposition of Gender Wage Differentials. Theoretical Economics Letters, 8, 1905-1934.

https://doi.org/10.4236/tel.2018.810125

Received: May 7, 2018

Accepted: June 23, 2018

Published: June 26, 2018

Copyright ( 2018 by author and Scientific Research Publishing Inc. This work is licensed under the Creative Commons Attribution International License (CC BY 4.0).

http://creativecommons.org/licenses/by/4.0/

\begin{abstract}
The purpose of this study is the effect of expansion of female labor demand on male labor demand for labor market reform to facilitate Japanese economic development. Firstly, the estimates using Hicks' (1970) partial elasticity of complementarity and Allen's (1938) partial elasticity of substitution revealed an increase in male labor demand when female labor demand increased in all three countries. The results were a relationship of complementarity in labor demand between male and female regular employees in the order of China, South Korea, Japan. However, a push factor or a pull factor is assumed to make up a complementarity relationship. Therefore secondly, the factor decomposition analysis of wage gap is used to investigate which factors are applicable. The gender wage gap consists of economic rationality and economic irrational discriminatory [Neumark (1988); Oaxaca and Ransom (1994)]. The gap was confirmed in all three countries. Although the actual gender average wage difference was small in China, "discriminatory preference theory" was suggested that there is underpayment of women in Japan and Korea. In Japan, as women have a high potential labor force participation rate, expansion of female labor demand seems promising as an economic policy, not least because of the declining population. Labor-related economic policies are needed, such as the creation of a fluid labor market in China, or the implementation of effective policies in Korea.
\end{abstract}

\section{Keywords}

Labor Demand, Complementarity, Substitution, Women, Men, Gender Wage Differentials, Japan, South Korea, China 


\section{Introduction: Expansion of Female Labor Demand as an Economic Issue}

The purpose of this study is to make policy recommendations for labor market reform to facilitate economic development in Japan. Japanese enterprises were obliged since 2015 to implement initiatives to promote expansion of female labor demand.

We perform an empirical analysis of the impact on male labor demand of the expansion of female labor demand. An analysis of the factors involved in such an expansion at Japanese enterprises is also carried out in comparison to Korean and Chinese enterprises.

According to World Economic Forum [1], the Global Gender Gap Index (GGGI), the economic gender gap is particularly big in Japan, Korea, and China, which all rank around $100^{\text {th }}$ among 144 countries (regions). The data show a gender gap in terms of labor demand "quantity" (the female ratio of workers), "quality" (the female ratio of managerial positions), and earnings. Ishizuka [2] has already investigated "quality" by promotions to managerial positions. This study estimates the expansion of female labor demand and a factor decomposition of the gender wage gap.

Part of the significance of this study lies in the fact that Japan, Korea, and China are all located in northeast Asia and have some commonalities, allowing them to learn from each other's experiences; in addition, there is hardly any comparative research, making this study somewhat pioneering. The Asian economy is active, and the role played within it, and within the global economy, by Japan, Korea, and China seems set to grow. Declining and aging in population are issues common to all three countries.

For many years, Japan, as the only developed major country in Asia, has been a leader in the global economy. However, it has a substantial gender gap, and is reforming working way [3] [4]. Although Korea has a bigger gender gap than Japan, it adopted an "effective quota system" which obliged businesses to have numerical targets for female employment and managerial positions in 2006. This policy has been shown to have an impact [5]. As a result of the introduction of an "effective quota system" in China in 1949 aimed at equality of employment between men and women as the planned economy, China is seen as a model of deep-rooted normalization of female employment and as an exemplar of a fluid labor market [6].

The first method of empirical analysis estimates Hicks' [7] partial elasticity of complementarity and Allen's [8] partial elasticity of substitution with regard to three factors of production, a male regular employee, a female regular employee, and capital ${ }^{1}$. The definition of a regular employee is a full-time permanent em-

\footnotetext{
${ }^{1}$ Substitution and complementarity analysis of regular and non-regular employees was carried out for Japan only. In Japan and Korea, the disparity between the contractual treatment of the two groups of workers is significant, and is itself an issue for discussion. However, in this study, the focus is mainly on regular employees, because this is the group that is subject to promotion and for whomcontractual treatment of men and women is uniform, making comparison possible.
} 
ployee. In Japan and Korea, they are under the work system peculiar to Japan.

The second method decomposes the gender wage gap into factors consistent with economic rationality and economic irrational discriminatory. The factor of discriminatory consists of an underpayment of women and an overpayment of men [9] [10]. That is, the origins of the relationships obtained from the first method are examined.

This study uses Chinese and Korean corporate data from a survey carried out in 2013, lent by RIETI, and Japanese corporate data obtained in 2015 using the same questionnaire.

This paper is constituted as follows. Section 2 analyzes the current situation, Section 3 explains the data, section 4 analyzes the econometric substitution and complementarity of the gender labor demand, and section 5 analyzes the econometric factor decomposition of the gender wage gap, in Japan, South Korea, and China.

\section{The Current Situation: GGGI and the Gender Labor Demand Gap in Japan, Korea, and China}

\subsection{GGGI in Japan, Korea and China}

How do the gender gaps in Japan, Korea, and China rank globally? Figure 1 shows overall ranking using the Global Gender Gap Index (GGGI). It shows that, in 2017, among the 144 countries (regions) covered, Japan ranked $114^{\text {th }}$, Korea $118^{\text {th }}$ and China $100^{\text {th }}$. This means that for all three countries the gender gap remains significant $[1]$.

Looking at trends in the overall GGGI ranking, the number of countries (regions) covered is increasing, but the order in which the three countries rank is unchanged. That said, in the four years since 2013, Japan has dropped nine positions in ranking, Korea seven and China thirty-one. While it is true that employment of women is embedded within Chinese business culture, there does seem to have been an impact due to progress made in the marketization of labor accompanying the creation of a market-orientated economy [11]. In addition, Ishizuka [12] noted, particularly in cities in central China, a slight increase in unemployed women who fulfill the role of "housewives" typical of developed countries.

Figure 2 shows the GGGI in 2017 in Japan, Korea, and China in more detail. The GGGI is divided into four fields of 1) economy, 2) education, 3) health, and 4) politics. As a reference, the scores of second-ranked Norway, $49^{\text {th }}$-ranked US, and tenth-ranked Philippines in Asia are also shown on the line graph. As a result of gender diversity management policies, the proportion of women on corporate boards in Norway has risen to about $40 \%{ }^{2}$, and it is exemplary in terms of actively adopting strategies that promote a work-life balance, whereby both work and the home/children are supported. Also, while it would be incorrect to say that either factor results from any active strategy on the part of its government,

${ }^{2}$ Norway did not adopt a quota system, considering the introduction of such a policy to be an infringement of corporate autonomy. 


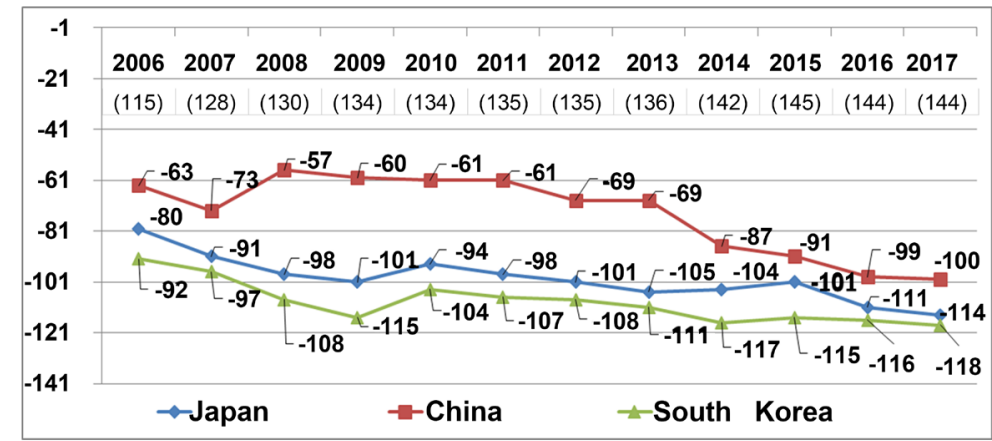

Figure 1. GGGI (Global Gender Gap Index): Trend in Overall Ranking. (Japan, South Korea, China). Data Source: World Economic Forum [1].

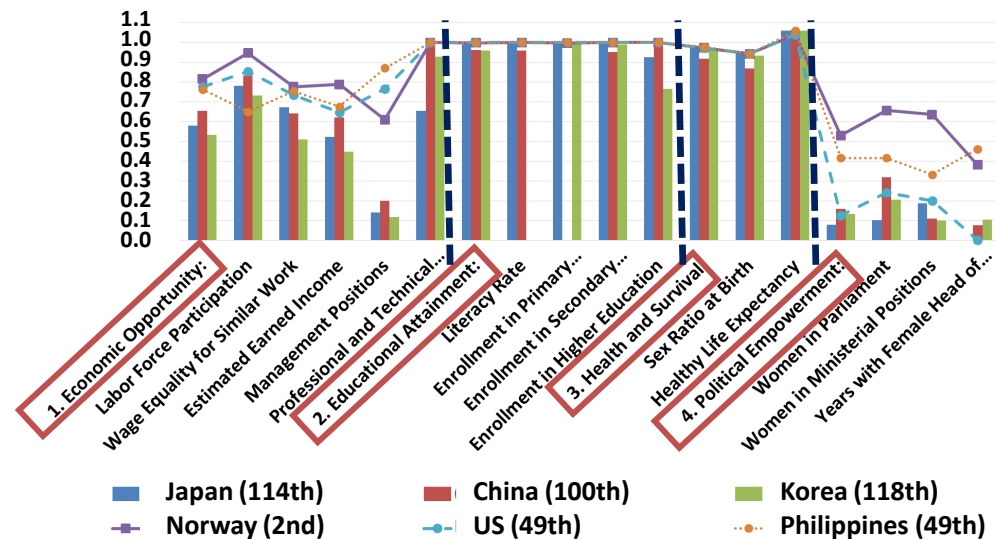

Figure 2. Details of GGGI (2017) (Japan, Korea, China, Norway, US, Philippines). Date Source: World Economic Forum [1].

the US has maintained a fertility rate of around 2.0, the level at which the population is sustained, and women themselves are choosing to work; in addition, the US ranks at the global top in terms of GDP.

The scores in Japan, Korea, and China for 2) education and 3) health are not problematic when compared to the scores of European countries and the US, with one exception ${ }^{3}$. The fields in which Japan's GGGI ranking has fallen significantly are 1) economics and 4) politics. These are both fields that impact the actual workings of society, and there is indeed substantial gender disparity in all three countries ${ }^{4}$.

${ }^{3}$ In 2) education, the only low score is "Enrollment in Higher Education." The Japanese gender gap in tertiary education can be quantified at 0.93 , with $61 \%$ of women receiving a higher education and $66 \%$ of men. In Korea, the same figures are $0.77,80 \%$ and $105 \%$, while in the whole China, at the level of secondary education (junior high/high school), the figures are $0.95,47 \%$ and $53 \%$. Treating the whole China as irrelevant, we can say that there is a gender gap in terms of the rate of higher education in Japan and Korea.

${ }^{4}$ In 4: Political Sector, Japan, Korea, and China all fall behind to Norway. The inferiority of the situation in Japan is particularly striking. China, not least because of the impact of socialism, has produced a certain level of female participation in the field of politics. Korea resembles Japan in that it falls behind Norway, but in recent years it has made significant progress: it has introduced a quota for female National Assembly members and for female elected local government representatives and also produced a female president. However, in this study, no deeper investigation will be made in this field. 
As it is the theme of this study, we will look in some detail at the economic elements of the index. Japan, Korea and China all fall behind Norway in the field overall. Looking at the components of the field, the largest differentials are, as already mentioned, in the female-to-male ratio of labor force participation (Labor Quantity), the female-to-male ratio of legislators, senior officials, and managers and the female-to-male ratio of professional and technical workers (Labor Quality), and the gender wage gap. Note that, although the differentials in China are higher than in Japan and Korea, care should be exercised in reading the data. This is because, of the five countries in Figure 2, only China is not an OECD member, and as many as a half the employees within the data for China overall are employed in primary industries, most notably agriculture. This means that, for China overall, the labor market is still developing. From an analytical viewpoint, this issue is resolved in principle in the next and subsequent sections by making comparisons and drawing conclusions based only on data for China's urban areas where employed households are concentrated, to reflect the relevant situation in China.

\subsection{Trends in the Male and Female Labor Force Participation Rates, Labor Market, and Labor Policies in Japan, Korea, and China}

Firstly, Figure 3 shows labor force participation for men and for women in each age group, as well as characteristics of the labor market in all three countries. The differences between the countries were smaller for men than for women, with the male labor force participation rate highest in Japan, followed by China overall, then Korea, then China's urban areas. For women, the highest labor force participation rate was in China overall, followed by Japan, then China's urban areas, then Korea. However, in China overall, around half of the population is involved in agriculture. This makes it more appropriate to use China's urban areas in any comparison with Japan and Korea, both of which are developed nations.

According to Ishizuka [2], for regular employees in Japan and Korea, the Japanese employment practices of age-based remuneration and lifetime employment are entrenched. Retirement age in Japan has in many cases moved from 60 to 65 , and enterprises are obliged by legislation that deals with the employment of older people to keep on any employee who wants to keep working until the age of $65^{5}$. Following two years of military service while young, Korean men tend to take up employment as regular employees and work in the same job until they retire $^{6}$. The labor market is solid, and both countries share the problem of regular

\footnotetext{
${ }^{5}$ Recently, a tendency has emerged to raise the retirement age with, for example, the government paying a subsidy to enterprises employing people until 66 and beyond. The context behind this trend is a rise in the pension age in response to the falling birth rate.

${ }^{6}$ In Korea, the revised Act on the Prohibition of Age Discrimination in Employment and Aged Employment Promotion has made it compulsory for firms with 300 or more employees to have a retirement age of 60 or older from 2016, with the same rule applying to firms with fewer than $300 \mathrm{em}$ ployees from 2017. In a survey of Korean enterprises, responses indicated that the retirement age for both men and women is in the late 50s (Ishizuka [13]).
} 


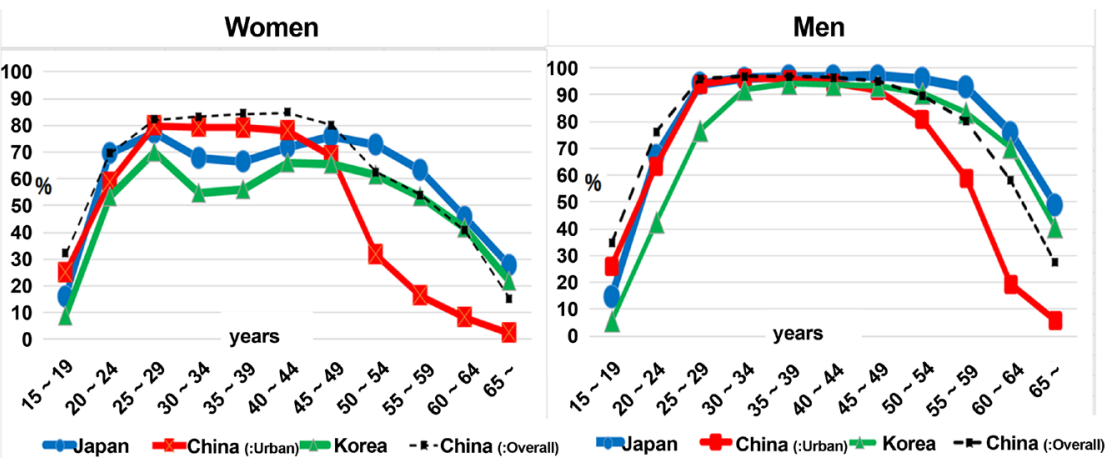

Figure 3. Labor Force Participation Ratio by Age Group for Each Gender. (Left: Female, Right: Male) (Japan, Korea, China Urban, China Overall) (Unit: \%). Data Source: For Japan, "Labor Force Participation Ratio by Age Group" of "Labor Force Survey (2010)" by the Ministry of Internal Affairs and Communications Statistics Bureau; for Korea, 'Labor Force Participation Ratio by Age Group' of "Yearbook of Labour Statistics" (2010)by ILO; For China, the author calculated by dividing the "Labor Forth Population" (="employed population" and "unemployed population") by the "Population" for each age group from both overall and urban figures provided of the "National Population Census" (2010, Volume 2, Tables 4-2 and 4-2a) by the National Bureau of Statistics of the State Council.

employees being in "work-type" employment for a long time. The curve of women's participation in the labor force, however, is M-shaped, because many women stop work to care for children, and in many cases the female employees on the right-hand side of this " $\mathrm{M}$ " are not regular employees.

In China, the labor market is fluid as it is in Europe and the US, and "job-type" employment is common. Retirement ages do exist, however. These are usually different for men and for women, being generally set at around 50 for women and around 60 for $\mathrm{men}^{7}$. Thanks to equal employment for men and women that accompanied the introduction of a planned economy in 1949, it is currently normal for women in China's urban areas to be employed ${ }^{8}$.

Next, to highlight trends in the male and female labor force participation rates in Japan, Korea, and China overall, Figure 4 shows trends in the labor force participation rate for only the productive population (aged 15 - 64). Limiting the data to the productive population reduces the impact of the aging population in the three countries.

${ }^{7}$ The State Council's 1957 provisional regulations relating to retirement age for workers and officials set the retirement age at state-run and other publicly-owned enterprises at 50 for female workers and 55 for female officials and at 60 for male workers and officials (though the retirement age for women and men doing heavy labor was set at 45 and 55, respectively). These retirement ages are still currently widely effective, including at ordinary businesses. In addition, the labor insurance regulations of 1951 and 1953 stated that male workers and officials who had reached 60 and had total service of 25 years, at least five of them at the enterprise in question, could receive an old-age pension after mandatory retirement; for female workers and officials, the relevant age is 50, with total service of 20 years, at least five of them at the enterprise in question (Ishizuka [11], p.24). In other words, retirement age for women is around 10 years earlier than men, and they are able to receive a pension at the same level as their low wages without carrying out market labor. Thus, the system was very much welcomed by women.

${ }^{8}$ In addition, Ishizuka [12] states that the normalization of female employment in China has been promoted by the short period of childrearing compared to women in other countries as a result of the constraints of the one-child policy, and also by the short working period compared to men. 


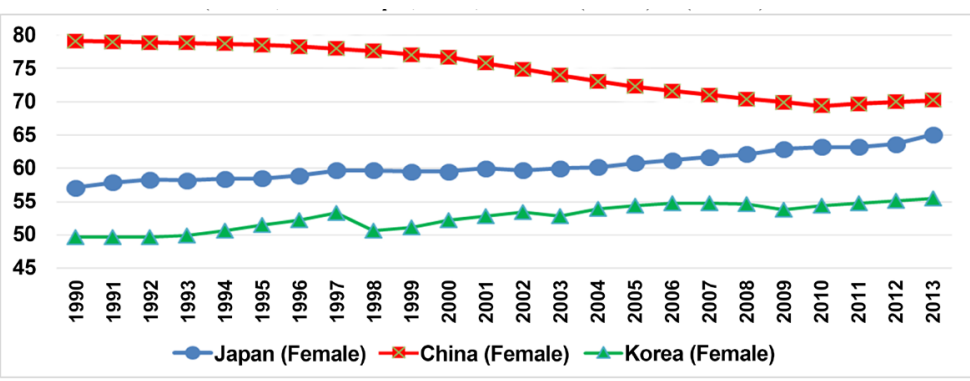

(a)

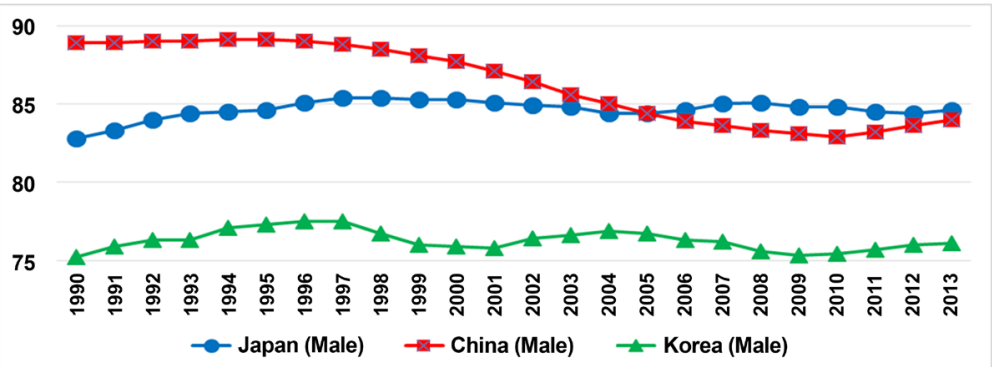

(b)

Figure 4. Trends in the Labor Force Participation Ratio. (Females, 15 - 64 in Japan, Korea, and China (Overall) (Unit: \%). Trends in the Labor Force Participation Ratio (Males, 15 - 64 in Japan, Korea and China (Overall), Unit: \%). Data Source: World Bank HP: Data Base (ages 15 - 64, modeled ILO estimate). Note: According to the definition of the labor force participation rate, the rate includes individuals 15 years of age and older. However, this data expresses population figures for the productive ages of "from 15 to 64 years of age."

The two charts show that the gender gap in the labor force participation rate in Japan and Korea has shrunk from about 25 points in 1990 to around 20 points now, as participation by women has gradually increased and participation by men has remained flat. Meanwhile, while the gender gap in labor force participation has stayed close to the 10 points seen in 1990, participation rates in China for both men and women fell after the reform of state-owned enterprises in the middle of the 1990s. Having been impacted by the economic downturn of the summer of 2008, they have increased slightly from a bottom in 2010. The current gender gap in the roughly calculated labor force participation rate has expanded to 14 points (women $70 \%$ and men $84 \%$ ).

We will now outline labor market-related policies in each of the three countries.

In Japan, the Gender Equality in Employment Act was implemented in 1986. In 2003, the Act on Advancement of Measures to Support Raising the Next Generation of Children was implemented, obliging business owners and municipalities that have 301 or more regular employees to give notification of a relevant action plan. In 2011, the obligation expanded to include employers and corporations with more than 100 employees ${ }^{9}$. This legislation expired in March ${ }^{9}$ As of June 2013, 67,177 ordinary enterprises with 101 or more employees had given notification that they had formulated a relevant action plan, with 1,588 of these enterprises receiving approval from the Ministry of Heath, Labour and Welfare. 
2015, but has been extended for 10 years. In 2015, the Act of Promotion of Women's Participation and Advancement in the Workplace was implemented, requiring enterprises with 301 or more employees to formulate a relevant action plan by April 1st, 2016. Specifically, each enterprise must: Step 1. Identify issues by analyzing 1) the proportion of women among its employees, 2) the gender gap in number of years of continuous employment, 3) working hours, 4) the proportion of women in management positions; Step 2.Formulate an action plan, file a report on it, and disseminate it within the enterprise; Step 3. Make this information widely available to the public.

In Korea, the Gender Equality in Employment Act was implemented in December 1987. Active measures to improve women's employment (hereafter "affirmative action programs") were added to this legislation in March 2006. When first introduced, these requirements applied to businesses and government institutions with 1000 or more regular employees, but in March 2008 they expanded to include those with 500 or more employees ${ }^{10}$. Analysis by Ishizuka [5] confirmed the impact of this initiative, with a rise in both the number of women employed and women in management positions. There was also an increase in the number of women on company boards, a factor not covered by the legislation. With anticipated further expansion of coverage to include businesses and government institutions with 100 or more employees, these positive impacts are expected to continue. The main objective of this affirmative action program is to mobilize women who are not sufficiently economic active to prevent a decline in Korea's international competitiveness as result of the ongoing decline in the birthrate and the aging of society, similar to what is being experienced in Japan. Also, a low proportion of female workers is seen as a sign of "indirect discrimination" by the business in question, and such businesses are required to make improvements. The specific achievement target is $60 \%$ of the average ratio of regular female workers and women in management in other enterprises of the same size in the same industry. All businesses and government institutions subject to the requirements are obliged to report to the government regarding their male and female workers by type of job, position, and gender by the end of March (Step 1). If they have not achieved the criteria for female employment, they are to present a female employment improvement plan by the end of March of the following year (Step 2). The government evaluates the quality and the transitional results of the implementation plan, offers administrative and financial support to "successful" enterprises, and issues transitional guidance to unsuccessful enterprises (Step 3).

In China, in the household registration system that divides the population into two groups, employee households are classified as "non-agricultural" (urban). Reform of state-owned enterprises started in earnest in the mid-1990s but, until a "labor market" was formed, only a limited number of employees were able to ${ }^{10}$ In 2006, 546 businesses across Korea were subject to the legislation. In 2007, the figure was 613. After the expansion to include businesses with 500 or more employees, the figure was 1425 in 2008 , 1607 in 2009, 1576 in 2010, and 1547 in 2011. 
move out of the region in which their household was registered and change classifications from agricultural to non-agricultural [13]. However, as the population is set to peak in around 2030, the household registration system is currently being partially relaxed. In 2015, the one-child policy was completely abolished, but the impact of this action seems limited. In practice, with the transition from a situation marked by the lingering impact of the planned economy to a market economy, the gender gap has tended to increase in terms of work-life balance, promotion at work, wages, types of jobs, and the application of new technology [11]. That is, female employment, including the employment of working mothers, is found on China's eastern seaboard, where many major cities are located and there has been significant economic development. However, in the center of the country, where economic development is only middling, there has been a slight increase, as in Japan and Korea, in the number of housewives staying at home to look after children [12]. Western China has failed to benefit sufficiently from economic development. Therefore, in this study, the focus is on China's urban areas and, in the empirical analysis in particular, comparisons with Japan and Korea are made using only enterprises located in the three large cities of the eastern seaboard.

Finally, falling birthrates and an aging society are having a significant impact on the labor markets in the three countries. In all three countries, the birthrate is between 1.0 and 1.5. It is highest in Japan, followed by Korea, and then China's urban areas. There has recently been a slight increase in the birthrate in Japan, but this is mainly a blip that has appeared as second-generation baby boomers pass the age of 40 and take their last opportunity to become parents. Looking only at the urban areas of China, the reduction in the birth rate is even more significant than in Korea [14]. Economic policies must secure the income required in the face of an expansion in expenditure. Specifically, pressing problems include improving welfare benefits for the elderly and securing the labor supply (in other words, the working population) needed in the near future. Looking at the public pension system, there is universal coverage in Japan, but in Korea and China, system reform is still ongoing.

\section{Data: "Corporate Survey on the Personnel Utilization of Men and Women (Japan 2015), (Rep. of Korea, China 2013)"}

The Japanese data used in this study comes from the "Corporate Survey on the Personnel Utilization of Men and Women (Japan 2015)" and the Korean and Chinese data from METI's Research Institute of Economy, Trade, and Industry's "Corporate Survey on Personnel Utilization of Men and Women (China and Korea, 2013)." Table 1 summarizes the data for each country by scale of enterprise and by sector.

The data for Japanese enterprises was obtained by the Nippon Research Center in mid-August 2015. A total of 1006 general affairs or human resources 
Table 1. Corporate survey on the personnel utilization of men and women (Japan 2015) (China, Rep. of Korea 2013).

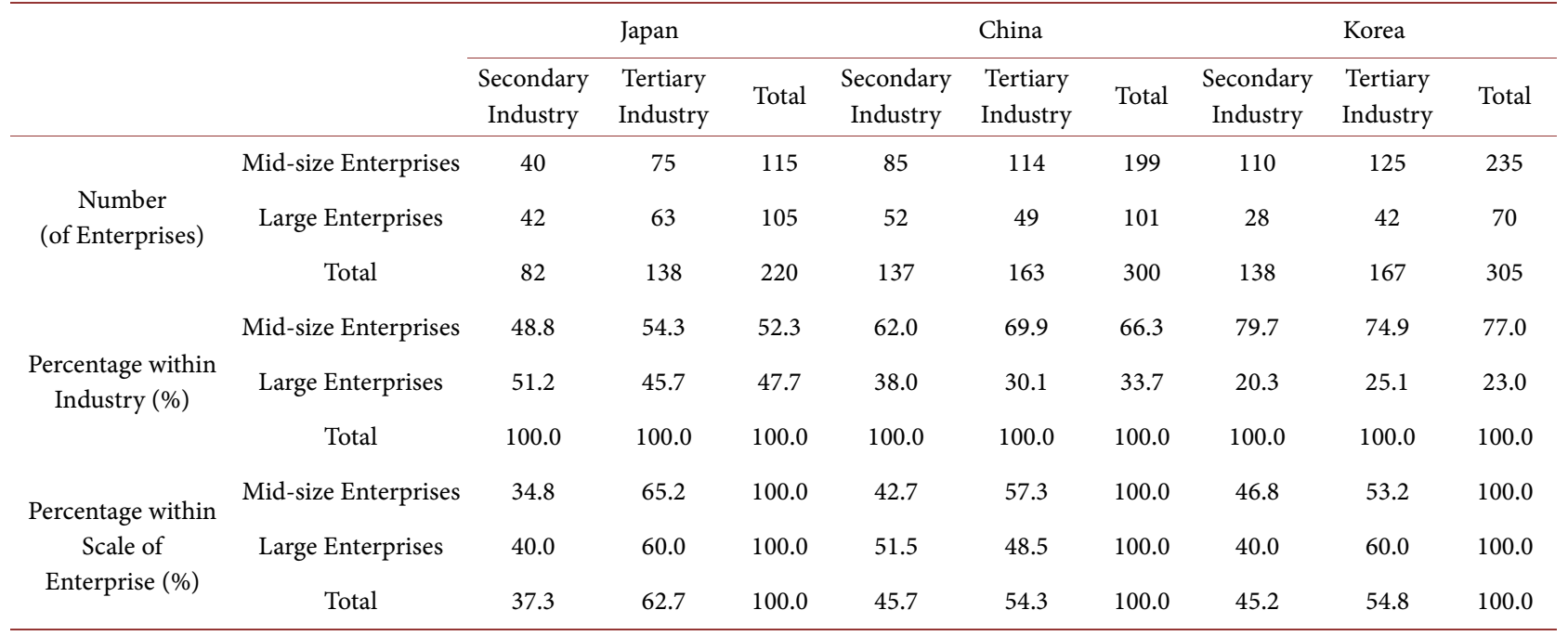

Note 1. In the classification of Japanese industries, tertiary industry includes five primary industry enterprises and three foreign investment enterprises whose industry is uncertain. Note 2 . The number of employees by scale of enterprise is: in Japan, 81 - 300 for mid-size enterprises and more than 300 for large enterprises; in China, 100 - 499 for mid-size enterprises and 500 or more for large enterprises; and in Korea, 100 - 299 for mid-size enterprises and 300 or more for large enterprises.

managers at enterprises across Japan with at least 80 employees were surveyed. Of these, 275 responded (a response rate of $27.3 \%$ ) and, with some responses rejected as incomplete, 220 samples were used in this study.

The Chinese and Korean data was obtained in a survey of numerical data obtained by interviews with human resources managers (or high-rank officials) in March-May 2013 in China and March-June 2013 in Korea, with a sample size of 300 enterprises in China and 305 enterprises in Korea. The enterprises surveyed were selected from a set of enterprises with at least 100 employees using a soft quota system based on 1) three broad industry classifications 2) scale (number of employees), and 3) city of location, with 4) ownership model being also moderately taken into consideration in China ${ }^{11}$. For China, the cities surveyed were Beijing, Shanghai, and Guangzhou in Guangdong. In Korea, in addition to the three cities of Seoul, Incheon, and Gyeonggi-do, about 10\% of surveys were administered in other regions. The three Chinese cities in the survey are considered advanced even within China, so the situation in these cities is not necessarily representative of the country as a whole. However, other cities will follow where these three cities lead, making them appropriate subjects to provide a portrait of the future of China's urban areas as a whole. For details of the survey and full results, please see Ishizuka [14]. The econometric software used was Stata (Version 14).

\footnotetext{
${ }^{11}$ Within the data for China, $14.0 \%$ of enterprises are state-run (medium enterprises $13.6 \%$, large enterprises $14.9 \%$ ) and $66.3 \%$ are domestic, private-sector enterprises. In addition, there was one medium and one large private-sector enterprise that used to be state-owned [14]. However, even privately listed companies are often under the umbrella of a state-owned enterprise. The proportioning of the sample according to enterprise type was not accomplished through a quota system imposed on the larger set, but they have been investigated in a similar way.
} 


\section{The Econometric Analysis of Substitution and Complementarity in Male and Female Labor Demand}

\subsection{Theoretical Models and Prior Research: The Substitution and Complementarity in the Gender Labor Demand, and Factors in the Gender Wage Gap}

There are various debates regarding substitution and complementarity elasticity, the first stage in our analysis. Stern [15] describes five types of elasticity of substitution and five types of elasticity of complementarity and notes differences in estimation results. Yamaguchi [16] also establishes four types of substitution and complementarity elasticity and conducts relevant estimations. There are various ongoing debates but, by recommending the use of multiple models, Hicks and Allen [17], as well as others, have further broadened the potential of elasticity analysis. Fundamental elements are Hicks' [17] partial elasticity of substitution and Allen's [15] partial elasticity of complementarity.

There is hardly any prior research estimating male and female labor demand using substitution and complementarity elasticity. Although Chinhui and Kim [18] did not use the elasticity analysis mentioned above, they estimated substitution effect model for gender labor supply based on wages using time series data in US. It was shown that female labor supply was substituted for less-educated male labor supply, and reducing the gender wage gap in the 1980s. However, it noted that labor demand decisions are made from the perspective of labor demand. Also, there is no evidence that an increase of educated women reduced men's wages.

Using 2005 and 2006 data for Japanese enterprises, Yamaguchi [16] estimated Hicks' partial elasticity of substitution and Allen's partial elasticity of complementarity and two other elasticities for regular and non-regular employees, and found a relationship of substitution. The relationship of substitution weakened in 2006. However, interpretation of the results was based exclusively on the historical background.

In summary, it is necessary to estimate multiple elasticities including "Hicks' partial elasticity of complementarity" and "Allen's partial elasticity of substitution". The analysis of substitution and complementarity reveals the relationship between capital and two types of labor, such as male and female labor demand, or regular and non-regular employees individually. To conduct a more detailed investigation, a second stage is an analysis of the wage gap.

In the first stage of analysis (substitution and complementarity), a substitution relationship is that a factor decreases (increases), when the other factor increases (decreases).And a complementarity relationship is that both factors rise or fall together. However, push factors and pull factors are assumed to make up a complementarity relationship.

A push factor is an increase in female labor demand based on an "economic rational evaluation of male and female labor as equal" that causes an increase in male labor demand based on an "economic rational evaluation of male and female 
labor as equal". A pull factors is an increase in female labor demand based on an "economic irrational and discriminate evaluation of female labor than male labor".

Therefore, in the second stage of analysis, the factor decomposition of wage gap is used to investigate which factors are applicable. In neoclassical labor economics, "discrimination" is the economic distance that exists between economic groups that possess the same productivity. In this study, the economic groups are men and women, and the economic distance is the wage gap ${ }^{12}$. When there is a wage gap, it is possible to verify the appropriateness of the factors that cause the wage gap by clarifying whether the gender gap economic rational based on Becker's "human capital theory" or if it is economic irrational based on Becker's [19] "discriminatory preference theory." 13 Yamaguchi [20] analyzed the productivity of men and women based on "discriminatory preference theory."

As an estimation method, Ishizuka [11] and others utilized Blinder-Oaxaca factor decomposition to clarify the impact of China's marketization on the gender wage gap, separating the state-owned sector (representative of planned economy tendencies) from the non-state owned sector (representative of market economy tendencies), using 2004 Chinese survey data. For state-owned enterprises, this analysis revealed differences between men and women consistent with economic rationality as a factor, but not with a factor for sexual discrimination. At private businesses, which have increased in number as a result of marketization, factors were roughly evenly split between those that were discriminatory and those that were consistent with economic rationality. In this study, which is based on Neumark [19] and Oaxaca and Ransom [20], gender wage gap factors are divided into those consistent with economic rationality and those that are discriminatory. Discriminatory factors are then further divided in two, allowing estimates regarding both underpayment of women and overpayment of men.

\subsection{Econometric Model}

The model for calculating the relationship of substitution and of complementarity of the three factors of production for each country and each enterprise is outlined below. Where male regular employees $=X_{1}$, female regular employees $=X_{2}$,

\footnotetext{
${ }^{12}$ In neoclassical economics, generally, in a perfectly competitive market that assumes rational behavior, wages are determined by the market, and workers of the same quality will receive the same wages if their productivity is the same. Women and men therefore have a relationship of perfect substitution. In other words, there is no room for the introduction of worker attributes such as gender differences between men and women. However, in labor economics, which is a form of applied economics, workers are not necessarily assumed to have equal quality. Other economic groups that may have an effect in labor economics include race, religion, and age, and there are also differences in effects between different occupations.

${ }^{13}$ Becker' [19] "discriminatory preference theory" is a theory of sexual discrimination on the part of enterprises (the demand side of labor). Because of the biased outlook of both consumers and male employee groups, which include male managers and employers, when there is a men and women with the same productivity, men are preferred and hired. Therefore, women come to be employed more cheaply than their labor productivity implies they should be.
} 
and capital $=X_{3}$, we have the linear homogeneous production function:

$$
Q=f\left(X_{1}, X_{2}, X_{3}\right)
$$

Further, specification with a translog production function gives:

$$
\begin{aligned}
& \ln Q=\ln \alpha_{0}+\sum_{i=1}^{3} \alpha_{i} \ln X_{i}+\frac{1}{2} \sum_{i=1}^{3} \sum_{j=1}^{3} \gamma_{i j} \ln X_{i} X_{j}, \\
& (i=1,2,3)(j=1,2,3)(i \neq j)
\end{aligned}
$$

Here, $\alpha_{0}, \alpha_{i} \gamma_{i j}$ are coefficients showing production techniques.

Assuming an enterprise determines the scale of the input of each factor of production in a way that maximizes profit $Q-\sum_{i=1}^{3} W_{i} W_{i}$, this gives rise to:

$$
W_{i}=\frac{\partial Q}{\partial X_{i}}(i=1,2,3)
$$

Here, $W_{i}$ is the real cost of the factor of production. Also, taking the wages that are the cost of $X_{2}$ as the real cost of the factor of production, and assuming a perfectly competitive market, the cost share versus production volume of the factor of production $i$ becomes:

$$
S_{i}=\frac{\partial \ln Q}{\partial \ln X_{i}}=\alpha_{i}+\sum_{j=1}^{3} \gamma_{i j} \ln X_{j},(i=1,2,3)(j=1,2,3)(i \neq j)
$$

Assuming the production function has linear homogeneity:

$$
\begin{gathered}
\sum_{i=1}^{3} S_{i}=1, \sum_{i=1}^{3} \alpha_{i}=1,(i=1,2,3) \\
\sum_{j=1}^{3} \gamma_{i j}=0,(i=1,2,3)(j=1,2,3)(i \neq j)
\end{gathered}
$$

Here,

$$
\gamma_{i j}=\gamma_{j i}
$$

is produced. In this study, based on Equation (8) and Equation (9) below, $\alpha_{i p} \gamma_{i 1}$, $\gamma_{i 2},(i=1,2)$ are estimated and, based on Equation $(6), \gamma_{31}, \gamma_{32}$ are estimated

When a translog production function is assumed, elasticity of complementarity is defined as:

$$
\begin{gathered}
\mathrm{C}_{i i}=\frac{1}{S_{i}}\left(S_{i}-1+\frac{\gamma_{i i}}{S_{i}}\right),(i=1,2,3) \\
C_{i j}=\frac{1}{S_{i}}\left(S_{j}+\frac{\gamma_{i j}}{S_{i}}\right),(i=1,2,3)(j=1,2,3)(i \neq j)
\end{gathered}
$$

It is possible to derive the value of Hicks' [17] partial elasticity of complementarity by substituting within Equation (8) and Equation (9) the estimated value of the cost share and coefficient obtained by applying an SUR mode ${ }^{14}$ to Equation (4), with Equation (7) as a constraint.

${ }^{14}$ SUR = Seeming Unrelated Regression, an estimate for apparently correlated factors. For more information on the SUR model, see Greene [21], pp. 602-607. 
Further, using

$$
E_{i j}=\frac{1}{S_{i} S_{j}} \frac{H_{i j}}{|H|}, H=\left[\begin{array}{cccc}
0 & 1 & 1 & 1 \\
1 & c_{11} & c_{12} & c_{13} \\
1 & c_{21} & c_{22} & c_{23} \\
1 & c_{31} & c_{32} & c_{33}
\end{array}\right],(\mathrm{i}=1,2,3)(j=1,2,3)(i \neq j)
$$

it is possible to estimate the value of Allen's [15] partial elasticity of substitution.

Specifically, S: the cost share numerical value, which is equal to the average wage $\times$ number of employees $\div$ value added (sales basis), $Q$ : the sales-based value added (sales - intermediate input costs; in millions of yen in Japan, tens of thousands of won in Korea, and thousands of yuan in China), $W_{i}$ : annual wages per employee(including bonuses, tax, and public pension premiums), $X_{1}$ : the number of male regular employees, $X_{2}$ : the number of female regular employees, and $X_{3}$ : the value of fixed assets (in millions of yen in Japan, tens of thousands of won in Korea, and thousands of yuan in China). In only model (4), $X_{1}$ : the number of regular male and female employees, and $X_{2}$ : the number of non-regular male and female employees.

\subsection{Estimation Results}

We will start with an explanation regarding how to read Tables 2-4. Table 2 shows Hicks' partial elasticity of complementarity $C_{i j}$ calculated by substituting the values in Table 1 in Equation (8) or Equation (9). The values in Table 1 are the results of estimating a simultaneous equation of $S_{1}$ (male regular employees) and $S_{2}$ (female regular employees) with an SUR model, based on Equation (4) in this study ${ }^{15}$. A positive value signifies that the factors of production have a relationship of complementarity, while a negative value signifies a relationship of substitution. In addition, the higher the numerical value, the stronger the relationship between the two factors, and the lower the numerical value, the weaker the relationship. Table 3 shows Allen's partial elasticity of substitution $E_{i j}$ calculated using numerical values including those in Table 2. A positive value signifies that the factors of production have a relationship of substitution, while a negative value signifies a relationship of complementarity. Thus, the same result is obtained if the signs of $\mathrm{C}$ and $\mathrm{E}$ are reversed, which implies that the estimations have been produced in a consistent manner. The interpretations in this study are, in principle, based on C. Table 4 is limited to the estimation results of the substitution/complementarity relationship of male and female labor demand, which have been extracted from Table 2 and Table 3.

In Table 4, all values of $C$ are positive and all values of $E$ are negative, confirming a relationship of complementarity in all three countries between male and female labor demand. The two models give consistent results. In other words, if the labor demand of female regular employees increases, so does the labor demand of male regular employees. Seen overall, $C$ is highest in China and

${ }^{15}$ At this point, null hypotheses for Equation (7) were estimated using a Wald test. All null hypotheses were rejected. 
Table 2. Estimation results for hicks partial elasticity of complementarity $C_{i^{*}}$

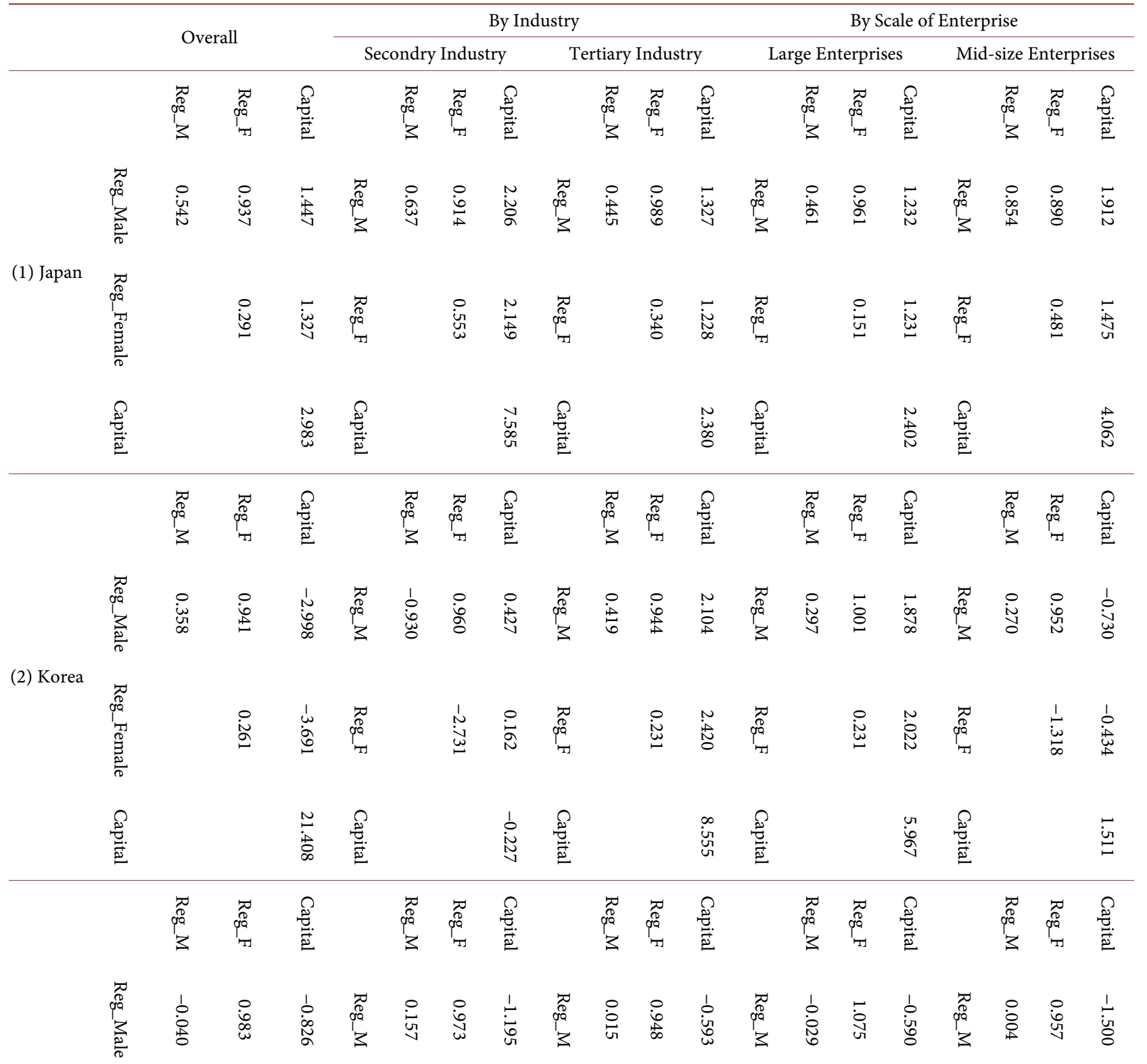

(3) China

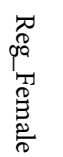

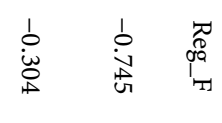

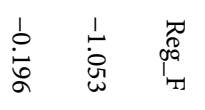

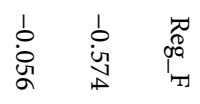

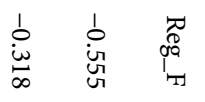

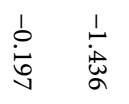
:
ஸे

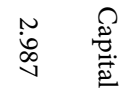
官
荵
î̀

(4) Japan

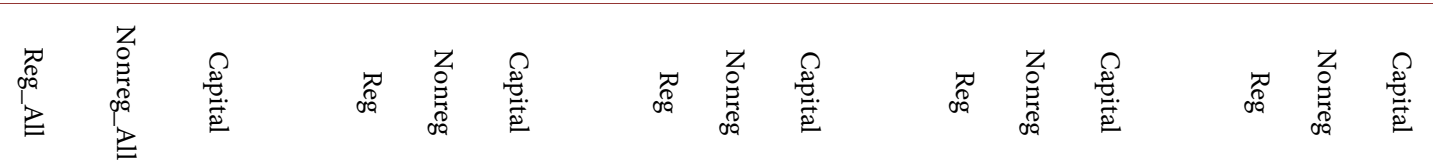

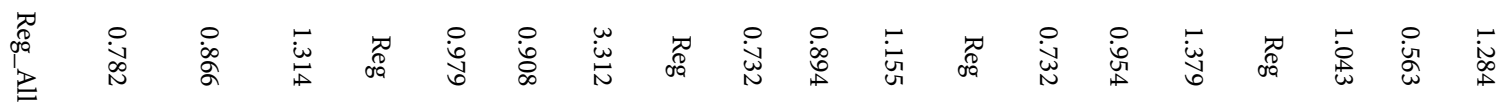




\section{Continued}

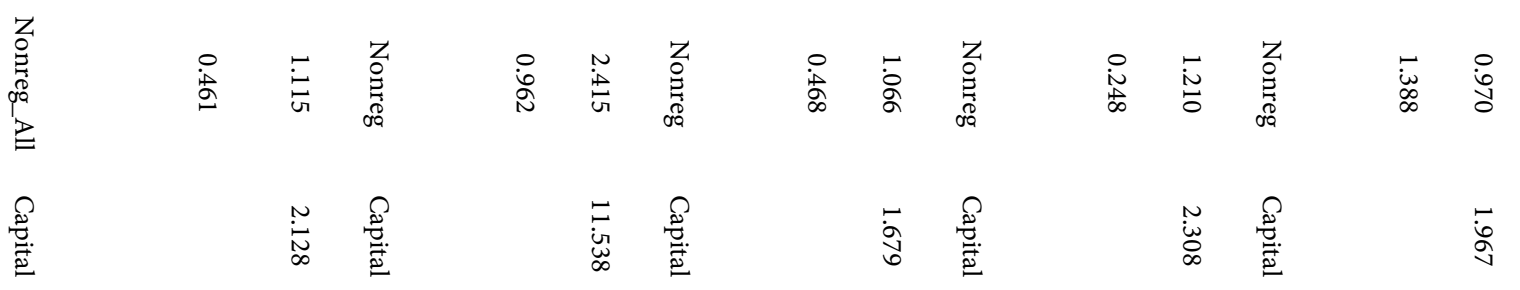

Data Source: "Corporate Survey on the Personnel Utilization of Men and Women (Japan 2015)"; "Corporate Survey on the Personnel Utilization of Men and Women (China, Rep. of Korea) 2013" by RIETI. Note 1. Based on Equation (4) in this paper, the values in Appendix Table 1, which are the results of estimates from the simultaneous equations for male regular employees $\mathrm{S}_{1}$ and female regular employees $\mathrm{S}_{2}$ using the SUR model, have been calculated by substituting into Equation (8) or (9).

Table 3. Estimation results for the Allen partial elasticity of substitution $E_{i r}$

Overall

\begin{tabular}{|c|c|c|c|c|}
\hline \multirow{4}{*}{ (1) Japan } & & Reg_M & Reg_F & Capital \\
\hline & Reg_M & -0.569 & -1.441 & 0.597 \\
\hline & Reg_F & & -1.087 & -0.799 \\
\hline & Capital & & & 1.457 \\
\hline \multirow{4}{*}{ (2) Korea } & & Reg_M & Reg_F & Capital \\
\hline & Reg_M & -2.069 & -5.086 & 0.005 \\
\hline & Reg_F & & \#\#\#\#\#\# & 1.065 \\
\hline & Capital & & & 2.038 \\
\hline \multirow{4}{*}{ (3) China } & & Reg_M & Reg_F & Capital \\
\hline & Reg_M & -2.471 & -4.353 & -1.363 \\
\hline & Reg_F & & -4.031 & 1.118 \\
\hline & Capital & & & 2.652 \\
\hline \multirow{4}{*}{ (4) Japan } & & Reg & Nonreg & Capital \\
\hline & Reg & -0.616 & -2.015 & 0.408 \\
\hline & Nonreg & & -2.092 & -1.157 \\
\hline & Capital & & & 1.110 \\
\hline
\end{tabular}

Data Source: Same as Table 2. Note 1. Using the values in Table 2, results have been calculated by substituting into Equation (10). As in Table 2, results are estimated by industry and enterprise scale. However, only the overall estimation results are displayed in this paper. Other estimations have generally been in line with the results from Table 2.

$E$ is highest in Korea. However, the largest and second largest values occur in China and Korea in both $C$ and $E$.

Looking at the numerical value of $\mathrm{C}$, the strongest relationship of complementarity is in China, with an overall value of 0.983 , with the relationship particularly strong for large enterprises (1.075) and tertiary sectors (0.948). The next strongest relationship is in Korea, with an overall value of 0.941 , with the relationship particularly strong in medium enterprises (0.952) and secondary sectors 
Table 4. Estimation results for the substitution and complementarity of Male and Fe male labor demand.

\begin{tabular}{|c|c|c|c|c|c|c|c|c|c|c|c|}
\hline & & \multicolumn{8}{|c|}{ Hicks Partial Elasticity of Complementarity $C_{i j}$} & \multicolumn{2}{|c|}{$\begin{array}{c}\text { Allen Partial } \\
\text { Elasticity of } \\
\text { Substitution } E_{i j}\end{array}$} \\
\hline & & \multirow{2}{*}{\multicolumn{2}{|c|}{ Overall }} & \multicolumn{3}{|c|}{ By Industry } & \multicolumn{3}{|c|}{ By Scale of Enterprise } & \multirow{2}{*}{\multicolumn{2}{|c|}{ Overall }} \\
\hline & & & & $\begin{array}{l}\text { Secondry } \\
\text { Industry }\end{array}$ & $\begin{array}{l}\text { Tertiary } \\
\text { Industr }\end{array}$ & & $\begin{array}{c}\text { Large } \\
\text { Enterprises }\end{array}$ & $\begin{array}{l}\text { Mid-siz } \\
\text { Enterpri }\end{array}$ & $\begin{array}{l}\text { ize } \\
\text { rises }\end{array}$ & & \\
\hline \multirow{3}{*}{$\begin{array}{c}\text { Regular Male } \\
\text { and Female } \\
\text { Employees }\end{array}$} & $\begin{array}{c}(1) \\
\text { Japan }\end{array}$ & 0.937 & * & $0.914 *$ & 0.989 & & 0.961 & 0.890 & & -1.441 & * \\
\hline & $\begin{array}{c}(2) \\
\text { Korea }\end{array}$ & 0.941 & $* *$ & $0.960 *$ & $0.944 *$ & ** & 1.001 & $0.952 *$ & $* * *$ & -5.086 & $* *$ \\
\hline & $\begin{array}{c}(3) \\
\text { China }\end{array}$ & 0.983 & * & 0.973 & 0.948 & * & $1.075 *$ & 0.957 & * & -4.353 & * \\
\hline $\begin{array}{c}\text { Regular and } \\
\text { Non-regular } \\
\text { Employees }\end{array}$ & $\begin{array}{c}(4) \\
\text { Japan }\end{array}$ & 0.866 & $* * *$ & 0.908 & $0.894 *$ & ** & 0.954 & 0.563 & $\dagger$ & -2.015 & $* * *$ \\
\hline
\end{tabular}

Data Source: Same as Table 2. Note 1. Excerpted from Table 2 and Table 3. Note 2. Significance is same as significance using the SUR model in Appendix Table 1. $\dagger: 0.1 \% ;{ }^{* *}: 1 \%$; ${ }^{* *}: 5 \%$; $: 10 \%$.

(0.960). Of the three countries, the relationship was weakest in Japan, with an overall value of 0.937 . The figures do not vary much, but the overall figure and the figures by sector and by size of enterprise, all show the same order: first China, followed by Korea, the Japan. This is likely because, although it has risen gradually (Figure 2), China has the smallest gender gap among the three countries, China's GGGI ranking is the highest among the three countries (Figure 1), and the labor market structure in China has historically normalized the labor demand of women (see Subsection 2.2 of this study). Korea ranks next likely because of the positive impact of the introduction of measures to promote expansion in female labor demand (Ishizuka [5]). These measures were introduced before similar measures were introduced in Japan. The figures for Japan have probably been enhanced by the promotion of policies for the expansion of labor demand as part of the "Promotion of Women" since 2012, and also by the underlying strength of the economy in 2015 when the survey data was collected (Ishizuka [4], [9]).

Estimation results of model (4) in Table 4 confirm a relationship of complementarity between regular and non-regular employees in Japan. The numerical value for the overall relationship of complementarity $\mathrm{C}$ is 0.866 . In other words, when the labor demand of regular employees increases, so does the labor demand of non-regular employees. The context includes an expansion in demand for both categories of labor thanks to relative scarcity in the Japanese labor market in 2015 in comparison to the previous year, and the continuing increase in the labor demand of non-regular employees, more of whom are women than men. Yamaguchi [16] found a declining trend for the relationship of substitution between the two in 2006. The results in this study are from ten years later, 2015, 
and are likely to have been impacted by the implementation of policies to reform working practices since 2012 and by the strength of the economy.

In addition, Table 2 and Table 3 show the relationship between demand for male and female labor and capital in the three countries. In China, as seen in Table 2, a relationship of substitution between male labor and capital and between female labor and capital was confirmed overall and for all sectors and all enterprise sizes. A substitution relationship between female labor demand and capital in China can also be derived from Table 3. For Korea, the overall and medium-sized enterprise values in Table 2, as well the results in Table 3, confirmed a relationship of substitution between male labor and capital and between female labor and capital. In Japan, for all values in Table 2, and for female labor and capital in Table 3, a relationship of substitution was confirmed. The background to this is likely to be that, in China, there is still a high volume of supply of labor including farmers (migrant workers), allowing the development of labor-intensive operations. In Japan, the rapid decline in the population has encouraged business development through the investment of capital. Korean businesses can be considered to engage in a relatively diverse range of operations.

In this section, a relationship of complementarity was verified between increases in female labor demand and increases in male labor demand for all three countries. In the next section, the factors within the relationship of complementarity are verified using factor decomposition of the gender wage gap.

\section{Factor Decomposition of Gender Wage Gap}

\subsection{Estimation Model}

In the previous section, a relationship of complementarity was derived for male labor demand and for female labor in the three countries. A relationship of complementarity means that an increase in female labor demand is accompanied by an increase in male labor demand. However, within the relationship of complementarity, as shown in Subsection 4.1, both push factors and pull factors are involved. Push factors are those in which female labor demand increases due to the equal evaluation of men and women, consistent with economic rationality. Pull factors are those which increase female labor demand due to treatment of women in an economic irrational manner that is discriminatory compared to that of men.

To resolve this point, earnings functions for men and women were estimated, and factor decomposition of the gender wage gap was carried out. Estimation is based on Neumark [19] and Oaxaca and Ransom [20], with the factors within the gender wage gap divided into elements consistent with economic rationality and discriminatory elements (underpayment of women and overpayment of men).

First, the Mincer earnings function as used in general gender data was estimated for men and for women for a situation without discrimination:

$$
\ln W_{i}=X_{i} B_{i},(i=m, f, \text { all })
$$


Here, $\ln W$ is the natural logarithm of hourly wages. On the basis of "human capital theory," $X$ is the number of graduates of a four-year university course or higher, the number of years of continuous employment, and age. It also includes two dummies to represent whether an enterprise belongs to a tertiary sector and is a large enterprise, distinctions made using corporate attributes. Within $i, m$ represents male, $f$ represents female, and all the combined male and female figure.

In addition:

$$
\operatorname{Ln}\left(W_{m}-W_{f}\right)=X_{m}\left(B_{m}-B^{*}\right)+X_{f}\left(B^{*}-B_{f}\right)+\left(X_{m}-X_{f}\right) B^{*}
$$

Here, the first term on the right of the equation represents "overpayment of men," and the second "underpayment of women," the third represents "the gap between men and women that is consistent with economic rationality."

As mentioned in Subsection 4.1, the third term represents the gender wage gap consistent with economic rationality, that is, the gap between the marginal productivity of men and of women due to differences in attributes such as number of years of continuous employment. This term is based on "human capital theory." The first and second terms represent the gender gap that is not consistent with economic rationality, based on Becker's [19] "discriminatory preference theory." This is the gender wage gap attributable to "discrimination."At enterprises in Japan and Korea in particular, attempts to reduce costs result in a difference between marginal productivity and marginal wage rate, and "overpayment of men" (the first term) and "underpayment of women" (the second term) are generated.

\subsection{Estimation Results}

The coefficients resulting from the estimation signify that, when $X$ increases by one unit, $W$ wages increase $[\mathrm{B} \times 100] \%$. For statistical significance, only results from the third decimal place are taken into account.

Table 5 shows that, among Japanese regular employees, men's wages rise as their number of years of continuous employment increases, and women's wages are higher for older women, women at large enterprises, and women in the service sector. Among Korean regular employees, both men and women see their wages rise as their number of years of continuous employment increases, but there is a negative correlation between age and wages. For women, wages are higher in the service sector. Among Chinese regular employees, for both men and women, wages are pushed up by length of labor demand and by working in the service sector. For women, wages are higher at medium-sized enterprises.

Table 6 shows the estimation results of factor decomposition of the gender wage gap. Simple average values for the gender wage gap are, in ascending order, $6.0 \%$ in China, $16.2 \%$ in Korea, and $17.0 \%$ in Japan. Looking in more detail at the figures reveals a large contribution to the gap from the "discriminatory element" (after deduction of the economic rational contribution from the gender 
Table 5. Estimation results for the Mincer earnings function. (Regular Employees in Japan, Korea, and China; Male and Female).

\begin{tabular}{|c|c|c|c|c|c|c|c|c|c|c|c|c|c|c|}
\hline \multirow{3}{*}{$\begin{array}{c}\text { Explanatory } \\
\text { Variable } \\
\text { age }\end{array}$} & \multicolumn{6}{|c|}{ Japan } & \multicolumn{3}{|c|}{ Korea } & \multirow{3}{*}{$\begin{array}{c}\begin{array}{c}\text { Explanatory } \\
\text { Variable }\end{array} \\
\text { age }\end{array}$} & \multicolumn{4}{|c|}{ China } \\
\hline & \multirow{2}{*}{$\begin{array}{l}\text { (Unit) } \\
\text { Years }\end{array}$} & \multicolumn{2}{|c|}{ Male } & \multicolumn{2}{|c|}{ Female } & \multicolumn{2}{|c|}{ Male } & \multicolumn{2}{|c|}{ Female } & & \multicolumn{2}{|l|}{ Male } & \multicolumn{2}{|c|}{ Female } \\
\hline & & 0.007 & & 0.058 & $* * *$ & -0.009 & $* * *$ & -0.012 & $\dagger$ & & 0.002 & & 0.009 & \\
\hline tenure & Years & 0.046 & $* * *$ & 0.017 & & 0.087 & $\dagger$ & 0.063 & $\dagger$ & tenure & 0.031 & $\dagger$ & 0.018 & * \\
\hline tenure 2 & & -0.001 & $\dagger$ & -0.001 & & -0.003 & $\dagger$ & -0.003 & $* * *$ & $\begin{array}{l}\text { Included in Urban } \\
\text { Family Register }\end{array}$ & -0.0001 & $* * *$ & -0.00003 & \\
\hline $\begin{array}{c}\text { University } \\
\text { Education or } \\
\text { Greater }\end{array}$ & Persons & 0.0001 & & -0.0001 & & 0.00001 & & \#\#\#\#\#\# & $* *$ & $\begin{array}{c}\text { University } \\
\text { Education or } \\
\text { Greater }\end{array}$ & 0.0000004 & $* *$ & 0.0000001 & \\
\hline $\begin{array}{l}\text { Large Enterprise } \\
\text { Dummy }\end{array}$ & $(=1)$ & 0.117 & & 0.410 & $* *$ & 0.001 & & 0.057 & & $\begin{array}{l}\text { Large Enterprise } \\
\text { Dummy }\end{array}$ & -0.049 & & -0.059 & ** \\
\hline $\begin{array}{l}\text { Tertiary Industry } \\
\text { Dummy }\end{array}$ & $(=1)$ & 0.034 & & 0.405 & $* *$ & 0.051 & & 0.079 & $* * *$ & $\begin{array}{l}\text { Tertiary Industry } \\
\text { Dummy }\end{array}$ & 0.066 & $* * *$ & 0.073 & $* * *$ \\
\hline Constant Term & & 2.124 & $\dagger$ & -0.422 & & 7.195 & $\dagger$ & 7.285 & $\dagger$ & Constant Term & 2.926 & $\dagger$ & 2.694 & $\dagger$ \\
\hline Number of obs & & 153 & & 139 & & 290 & & 291 & & Number of obs & 300 & & 280 & \\
\hline Adj R-squared & & 0.107 & & 0.095 & & 0.200 & & 0.139 & & Adj R-squared & 0.113 & & 0.085 & \\
\hline
\end{tabular}

Note 1 . The natural $\log$ of the hourly wage has been estimated as the explained variable using OLS. Note 2. p values for statistical significance are as follows: †: $0.1 \%$; **: $1 \%$; ${ }^{* *}: 5 \%$; $* 10 \%$.

Table 6. Estimation Results for Decomposition Analysis of the Factors Involved in the Gender Wage Gap (Regular Employees in Japan, Korea, China).

(a)

\begin{tabular}{|c|c|c|c|c|}
\hline \multirow{4}{*}{ Japanese Enterprises } & \multirow{3}{*}{$\begin{array}{c}\text { Gender Wage } \\
\text { Gap }\end{array}$} & \multicolumn{2}{|c|}{ Discriminatory Factors } & \multirow{3}{*}{$\begin{array}{c}\text { Productivity Gap } \\
\text { Factors }\end{array}$} \\
\hline & & \multicolumn{2}{|c|}{ Overpayment of Underpayment of } & \\
\hline & & Men & Women & \\
\hline & LN (Wm-Wf) & $\mathrm{Xm}\left(\mathrm{Bm}-\mathrm{B}^{\star}\right)$ & $\mathrm{Xf}\left(\mathrm{B}^{*}-\mathrm{Bf}\right)$ & $(\mathrm{Xm}-\mathrm{Xf}) \mathrm{B}^{*}$ \\
\hline Age & -1.79 & -0.34 & -1.47 & 0.02 \\
\hline Tenure & 0.40 & 0.004 & 0.29 & 0.10 \\
\hline Tenure $^{\star *} 2$ & -0.22 & 0.07 & -0.16 & -0.13 \\
\hline $\begin{array}{c}\text { University Education or } \\
\text { Greater }\end{array}$ & 0.01 & -0.002 & 0.01 & 0.01 \\
\hline Large Enterprise Dummy & -0.14 & 0.002 & -0.14 & - \\
\hline Tertiary Industry Dummy & -0.23 & 0.02 & -0.25 & - \\
\hline Constant Term & 2.55 & 0.37 & 2.17 & - \\
\hline Total & 0.58 & 0.12 & 0.45 & 0.01 \\
\hline (Percentage of Total) & $100.0 \%$ & $21.2 \%$ & $77.3 \%$ & $1.6 \%$ \\
\hline Difference in Hourly Wage & 480 yen & 102 yen & 371 yen & 7 yen \\
\hline
\end{tabular}

\begin{tabular}{|c|c|c|c|}
\hline \multirow{4}{*}{$\begin{array}{c}\text { Japanese Enterprise } \\
\text { Average Hourly Wage for Men } \\
1749 \text { yen }(100.0 \%)\end{array}$} & \multirow{3}{*}{$\begin{array}{c}\text { Gender Wage } \\
\text { Gap } \\
480 \text { yen } \\
(17.0 \%)\end{array}$} & \multicolumn{2}{|c|}{$\begin{array}{c}\text { Economically Rational Productivity Gap Factors: } 7 \\
\text { yen }(1.6 \%)\end{array}$} \\
\hline & & \multirow{2}{*}{$\begin{array}{l}\text { Discriminatory } \\
\text { Factors } 473 \text { yen } \\
\quad(98.4 \%)\end{array}$} & $\begin{array}{c}\text { Overpayment Factor of Men: } 102 \\
\text { yen }(21.2 \%)\end{array}$ \\
\hline & & & $\begin{array}{l}\text { Underpayment Factor of Women: } \\
\text { 371yen }(77.3 \%)\end{array}$ \\
\hline & \multicolumn{3}{|c|}{ fe Hourly Wage for Women 1269 yen (83.0\%) } \\
\hline
\end{tabular}


(b)

\begin{tabular}{|c|c|c|c|c|}
\hline \multirow{3}{*}{ Korean Enterprises } & \multirow{2}{*}{$\begin{array}{c}\text { Gender Wage } \\
\text { Gap }\end{array}$} & \multicolumn{2}{|c|}{ Discriminatory Factors } & \multirow{2}{*}{$\begin{array}{l}\text { Productivity } \\
\text { Gap Factors }\end{array}$} \\
\hline & & $\begin{array}{l}\text { Overpayment of } \\
\text { Men }\end{array}$ & $\begin{array}{l}\text { Underpayment } \\
\text { of Women }\end{array}$ & \\
\hline & LN (Wm-Wf) & $\mathrm{Xm}\left(\mathrm{Bm}-\mathrm{B}^{\star}\right)$ & $\mathrm{Xf}\left(\mathrm{B}^{*}-\mathrm{Bf}\right)$ & $(\mathrm{Xm}-\mathrm{Xf}) \mathrm{B}^{*}$ \\
\hline Age & 0.09 & 0.14 & 0.001 & -0.05 \\
\hline Tenure & 0.23 & -0.005 & 0.12 & 0.12 \\
\hline Tenure $^{\star \star} 2$ & -0.05 & 0.01 & 0.002 & -0.06 \\
\hline $\begin{array}{c}\text { University Education or } \\
\text { Greater }\end{array}$ & 0.01 & 0.005 & 0.01 & -0.0005 \\
\hline Large Enterprise Dummy & -0.01 & -0.003 & -0.01 & - \\
\hline Tertiary Industry Dummy & -0.02 & 0.0004 & -0.02 & - \\
\hline Constant Term & -0.09 & -0.10 & 0.01 & - \\
\hline Total & 0.16 & 0.04 & 0.11 & 0.01 \\
\hline (Percentage of Total) & $100.0 \%$ & $26.3 \%$ & $68.8 \%$ & $4.9 \%$ \\
\hline Difference in Hourly Wage & 2489 won & 653 won & 1712 won & 122 won \\
\hline
\end{tabular}

Economically Rational Productivity Gap Factors: 122 won $(4.9 \%)$

\begin{tabular}{|c|c|c|c|}
\hline \multirow{3}{*}{$\begin{array}{c}\text { Korean Enterprises Average } \\
\text { Hourly Wage for Men 15,389 } \\
\text { won }(100.0 \%)\end{array}$} & \multirow{3}{*}{$\begin{array}{c}\text { Gender Wage } \\
\text { Gap } 2489 \text { won } \\
(16.2 \%)\end{array}$} & \multirow{3}{*}{$\begin{array}{l}\text { Discriminatory } \\
\text { Factors } 2365 \text { won } \\
\quad(95.1 \%)\end{array}$} & \\
\hline & & & $\begin{array}{c}\text { Overpayment Factor of Men: } 1712 \\
\text { won }(26.3 \%)\end{array}$ \\
\hline & & & $\begin{array}{c}\text { Underpayment Factor of Women: } \\
1712 \text { won }(68.8 \%)\end{array}$ \\
\hline
\end{tabular}

(c)

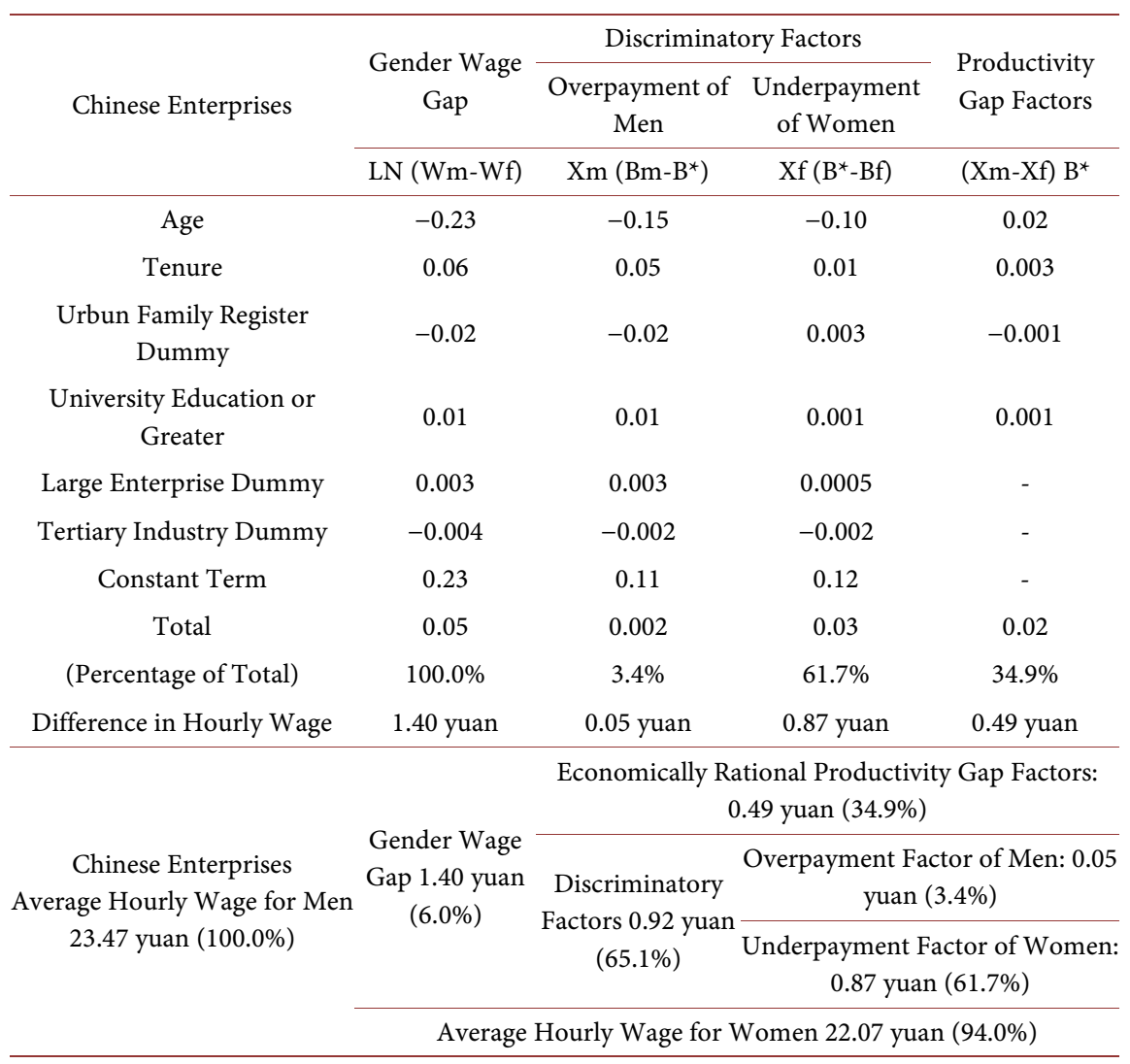


gap in marginal productivity) of, in ascending order, $65.1 \%$ in China, $95.1 \%$ in Korea, and $98.4 \%$ in Japan. In detail, "underpayment of women" is $61.7 \%$ and "overpayment of men" is $3.4 \%$ in China, with the equivalent figures, $68.8 \%$ and $26.3 \%$ in Korea, $77.3 \%$ and $21.2 \%$ in Japan.

In Japan, the gender gap in average wages for regular employees is relatively large at $17.0 \%$. The most significant factor expanding the gender wage gap based one conomic irrational discrimination is the 0.40 gender wage gap attributable to number of years of continuous employment. Meanwhile, it seems that the most significant factor reducing the gender wage gap (at -1.79) is the system whereby wages increase as employees get older. Indeed, the breakdown of the age contribution shows significant negative contributions from underpayment of women (-1.47) and from overpayment of men (-0.34). In addition, large enterprises and tertiary sectors reduce the discriminatory impact of the underpayment of women.

In Korea, the biggest contributor to the gender wage gap (at 0.23 ) is the number of years of continuous employment, and it is clear that underpayment of women is particularly important $(0.12)$. On the other hand, economic rational causes of disparity are similar to those in Japan.

In China, the gap in average wages themselves is very small at $6.0 \%$, and even components such as the underpayment of women in Table 6 have low values. Also, as mentioned in the previous section, historically, the structure of the Chinese labor market has normalized the female labor demand (Subsection2.2 of this study), further confirming that the theory being discussed is not applicable to China.

In summary, in the same order as in the substitution and complementarity analysis in the previous section, the contribution from the economic irrational discriminatory component is largest in Japan, followed by Korea, and then China. Also, the contribution from the underpayment of women is significant. The proportion of the gender wage gap attributable to discrimination with no basis in economic rationality is $98.4 \%$ for regular employees at Japanese enterprises and $95.1 \%$ at Korean enterprises. This study found that this was largely because, consistent with "discriminatory preference theory," women are employed at wages lower than implied by marginal productivity in human capital theory. This is either due to cost-cutting or, in Japan and Korea, because of female labor demand policies.

In other words, the labor demand of male and female regular employees expands in a complementary manner. However, this is largely attributable to an increase in labor demand for male regular employees causing an increase in labor demand for female regular employees under conditions in which female regular employees are evaluated in an economic irrational, discriminatory fashion in comparison to men (the pull factor in Subsection 4.1). According to Ishizuka [6], raising the proportion of regular employee management roles held by women to above $40 \%$ would eliminate this discriminatory component from 
the labor market ${ }^{16}$.

\section{Conclusion: Proposal of Policies for the Reform of Japan's Labor Market}

The purpose of this study is to make policy recommendations for labor market reform to facilitate economic development in Japan. Economic analysis was carried out regarding the effect of the expansion of female labor demand on male labor demand, and regarding the factors involved in such effects, at Japanese enterprises (which have been obliged since 2015 to implement initiatives to promote expansion of female labor demand), in comparison to Korean and Chinese enterprises.

Korea has a solid labor market with Japanese-like labor demand practices. However, in Korea, expansion of female labor demand became obligatory 10 years earlier than in Japan. In China, the labor market is fluid and female labor demand is normalized, facts that should acknowledged when making comparisons. The estimations in this study were based on corporate survey data for a single financial year (2013 for China and Korea; 2015 for Japan).

In the first analysis, Hicks' [17] partial elasticity of complementarity and Allen's [8] partial elasticity of substitution were estimated, and it was found that, when enterprises increased the labor demand of female regular employees, there is currently an impact on mainstream male regular employees. According to the estimation results, in all three countries, a relationship of complementarity in labor demand between male and female regular employees was confirmed. In other words, increases in the labor demand of female regular employees were found to occur in parallel with increases in the labor demand of male regular employees. Specifically, the numerical value for overall complementarity, by sector, and by scale of enterprise was highest in China, followed by Korea, and then Japan. The relationship between regular employees and non-regular employees was estimated for Japan only, and a weak relationship of complementarity was identified.

In short, Japan and Korea have the most significant gender gaps of all developed countries, although female labor demand is currently being promoted alongside male labor demand in both countries. Complementarity is stronger in Korea, probably because numerical targets for female labor demand became compulsory 10 years earlier than in Japan. China already has a history of normalizing female labor demand.

Next, as a second analysis, factor decomposition of the gender wage gap was carried out to clarify the factors within the estimation results of the first analysis. The gender wage gap was divided into a component consistent with economic rationality and discriminatory components inconsistent with economic rationality (itself consisting of two components: underpayment of women and overpay-

${ }^{16}$ The ratio of women in managerial positions in this data was about $20 \%$ for Japan and Korea and $42 \%$ in China (Ishizuka [6] [13]). 
ment of men), and the relative contributions of these components were estimated. In all three countries, a gender wage gap was confirmed, and it was inferred that the most significant factor in this was the discriminatory component of underpayment of women. That said, average hourly wages of Chinese female regular employees stand at $94 \%$ of the male rate. This is a small gap in comparison to the equivalent figures in Japan and Korea, which are $83.0 \%$ and $83.8 \%$ respectively. Within the gender gap in average wages, the component attributable to economic irrational discrimination is lower in China, at 65.1\%, against $\mathbf{9 8 . 4 \%}$ in Japan and $\mathbf{9 5 . 1 \%}$ in Korea. In other words, women are employed at wages lower than those implied within human capital theory by marginal productivity, a tendency consistent with "discriminatory preference theory." This is to reduce costs or, in Japan and Korea, because of policies to increase female labor demand. Future challenges include identifying and understanding trends related to these estimates using time-series data.

In terms of policy proposals, Japan in particular would benefit from labor market reforms promote female labor demand by tapping into the significant female potential labor force. Such policies would prevent a decline in the work force caused by a reduced population. The estimations in this study found that an expansion in female labor demand does not cause a reduction in male labor demand. The gender wage gap includes an element of discrimination between regular male and female employees, inconsistent with economic rationality; this would disappear if the proportion of women in management roles rose above $40 \%$, as in China (Ishizuka [6]). Economic policies that further promote the development of female labor demand could contribute to the revitalization of the Japanese economy. In implementing labor-related economic policies that will make achieving work-life balance possible for both men and women, policies such as making the labor market more fluid by increasing the number of "job-type" regular employees, as in China, or implementing the kind of strategies that have proved effective in Korea should be considered.

\section{Acknowledgements}

I appreciate having obtained the valuable comments from many researchers in this study's presentations at "the Japanese Economic Association Conference 2016" (in Waseda University), at "the Japanese Association for Chinese Economy and Management Studies Conference 2016" (in Keio University), at "EASP: the East Asian Social Policy Conference 2017" (in Nagoya University in Japan), at "IAFFE Conference 2017" (in Sungshin University in South Korea), and at "the Labor Economic Conference 2017" (in Tokyo University). Of course, I have the responsibility for the contents of this article. And I appreciate having obtained the valuable reviews also from the referee of this journal.

I'm thankful that I was given access to "A Corporate Survey on the Human Resources Utilization of Men and Women (China, Rep. of Korea) 2013" by RIETI: (the Research Institute of Economy, Trade and Industry) of a branch of METI: (the Ministry of Economy, Trade and Industry). 


\section{References}

[1] World Economic Forum (2017) The Global Gender Gap Report 2017. http://www3.weforum.org/docs/WEF_GGGR_2017.pdf

[2] Ishizuka, H. (2016) An Empirical Analysis of Women's Promotion in Japanese Companies: Comparison with Chinese and Korean Cases. Theoretical Economics Letters, 6, 570-582. https://doi.org/10.4236/tel.2016.63063

[3] Ishizuka, H. (2014) Gender Diversity in Management and Work-Life Balance Policies Have Started in Japan!: Comparison with Labor Markets in China and Korea. In panel "Changing Labor Market in Asia", Shanghai Forum 2014 (at Fudan University). http://www.voxeu.org/article/gender-diversity-management-japan

[4] Ishizuka, H. (2018) Economics of Work Style and Annual Income. Nippon Hyoron Sha co. Ltd. https://www.nippyo.co.jp/shop/book/7699.html

[5] Ishizuka, H. (2014) Does Gender Diversity in Management Contribute to Profitability, Productivity and AA System in Japan, China and Korea? RIETI (Ministry of Economy, Trade and Industry in Japan) Discussion Paper Series, 14-J-029. http://www.rieti.go.jp/en/publications/summary/14050010.html

[6] Ishizuka, H. (2017) An Empirical Analysis of the Impact of Japanese Enterprise Profitability on Gender Diversity in Economic Policies and Quota System: A Comparison with South Korean and Chinese Cases. Modern Women and Careers, 9, 51-64. http://id.nii.ac.jp/1133/00002682/

[7] Hicks, J. (1970) Elasticity of Substitution Again: Substitutes and Complements. $O_{X}$ ford Economic Papers, 22, 289-296.

https://EconPapers.repec.org/RePEc:oup:oxecpp:v:22:y:1970:i:3:p:289-96 https://doi.org/10.1093/oxfordjournals.oep.a041166

[8] Allen, G.D. (1938) Mathematical Analysis for Econo Mists. Macmillan, London. https://archive.org/details/mathematicalanal033535mbp

[9] Neumark, D. (1988) Employers' Discriminatory Behavior and the Estimation of Wage Discrimination. Journal of Human Resources, 23, 279-295. http://www.jstor.org/stable/pdfplus/145830

[10] Oaxaca, R.L. and Ransom, M.R. (1994) On Discrimination and the Decomposition of Wage Differentials. Journal of Econometrics, 61, 5-21. http://www.sciencedirect.com/science/article/pii/0304-4076(94)90074-4

[11] Ishizuka, H. (2010) Economic Analysis of Chinese Labor Market: Working Behavior of Chinese Men and Women in Urban Areas Analyzed in Terms of Economic and Social Systems. Keisoshobo. http://www.keisoshobo.co.jp/book/b245413.html

[12] Ishizuka, H. (2014) An Empirical Analysis of "the Type of Full-Tame Housewives in the Developed Countries": With CGSS 2006 and 2008. The Journal of Ohara Institute for Social Research, 667, 51-70. http://oisr-org.ws.hosei.ac.jp/images/oz/contents/667-10.pdf

[13] Du, J. and Ishizuka, H. (2014) Foreign Direct Investment and Employment. In: Minami, R., Kim, K.S. and Makino, F., Eds., Lewisian Turning Point in the Chinese Economy: Comparison with East Asian Countries, Palgrave Macmillan, UK, 136-154. https://www.palgrave.com/jp/book/9781137397256

[14] Ishizuka, H. (2014) Real Condition and Problem of Gender Diversity in Management in Japan, China, and South Korea: As a Result of 605 Companies' Survey by "the Corporate Survey on the Human Resources Utilization of Men and Women (China, Korea) 2013”. RIETI (Ministry of Economy, Trade and Industry in Japan) Discussion Paper Series 14-J-010. 
http://www.rieti.go.jp/en/publications/summary/14020002.html

[15] Stern, D.I. (2011) Elasticities of Substitution and Complementarity. Journal of Productivity Analysis, 36, 79-89. http://hdl.handle.net/10.1007/s11123-010-0203-1 https://doi.org/10.1007/s11123-010-0203-1

[16] Yamaguchi, M. (2011) Econometric Analysis on the Complementary and Substitution of Regular Employee and Non-Regular Employee. Japan Economic Research, 64, 27-55. http://www.jcer.or.jp/academic_journal/jer/PDF/64-02.pdf

[17] Hicks, J.R. and Allen, R.G.D. (1934) A Reconsideration of the Theory of Value, Part II. A Mathematical Theory of Individual Demand Functions. Economica, 1-2 196-219. http://www.jstor.org/stable/2548749 https://doi.org/10.2307/2548749

[18] Juhn, C. and Kim, D.I. (1999) The Effects of Rising Female Labor Supply on Male Wages. Journal of Labor Economics, 17, 23-48.

https://ssl.uh.edu/ cjuhn/Papers/docs/209912.pdf https://doi.org/10.1086/209912

[19] Becker, G.S. (1971) The Economics of Discrimination. 2nd Edition, University of Chicago Press, Chicago.

http://www.press.uchicago.edu/ucp/books/book/chicago/E/bo22415931.html https://doi.org/10.7208/chicago/9780226041049.001.0001

[20] Yamaguchi, K. (2011) Labor Productivity and Gender Equality: Why Do Japanese Firms Keep Failing, What They Should Do, and What the Government Should Do? RIETID iscussion Paper Series11-J-069.

https://www.rieti.go.jp/en/publications/summary/11100003.html

[21] Greene, W.H. (2011) Econometric Analysis. 7th Edition, Pearson Education Limited. http://pages.stern.nyu.edu/ wgreene/Text/econometricanalysis.html 


\section{Appendix}

Appendix Table 1. Estimation Results from the SUR Model.

\begin{tabular}{|c|c|c|c|c|c|c|c|c|c|c|c|c|c|c|}
\hline \multirow{3}{*}{$\begin{array}{c}\text { (1) Japan } \\
\text { (Explained Variable) }\end{array}$} & \multirow{2}{*}{\multicolumn{4}{|c|}{ Overall }} & \multicolumn{4}{|c|}{ By Industry (Note 2) } & \multicolumn{6}{|c|}{ By Scale of Enterprise (Note 3) } \\
\hline & & & & & \multicolumn{2}{|c|}{ Secondary Industry } & \multicolumn{2}{|c|}{ Tertiary Industry } & \multicolumn{2}{|c|}{ Large Enterprises } & \multicolumn{4}{|c|}{ Mid-size Enterprises } \\
\hline & \multicolumn{2}{|l|}{ S1 } & \multicolumn{2}{|l|}{ S2 } & S1 & S2 & S1 & S2 & \multirow{2}{*}{$\begin{array}{c}\text { S1 } \\
0.395 \dagger\end{array}$} & S2 & \multicolumn{2}{|l|}{ S1 } & \multicolumn{2}{|l|}{$\mathrm{S} 2$} \\
\hline $\begin{array}{l}\text { LN (Regular Male } \\
\text { Employee/Capital) }\end{array}$ & 0.546 & $\dagger$ & -0.118 & * & $0.661 \dagger$ & $-0.121 *$ & $0.433 \dagger$ & -0.024 & & -0.081 & 0.779 & $\dagger$ & -0.189 & \\
\hline $\begin{array}{l}\text { LN (Regular Female } \\
\text { Employee/Capital) }\end{array}$ & -0.118 & * & 0.347 & $\dagger$ & $-0.121 *$ & $0.264 \dagger$ & -0.024 & $0.310 \dagger$ & -0.081 & $0.268 \dagger$ & -0.189 & & 0.471 & $\dagger$ \\
\hline Constant Term & 1.135 & $\dagger$ & 1.197 & $\dagger$ & $1.408^{\star * *}$ & $* 0.910 \dagger$ & $1.081 \dagger$ & $1.131 \dagger$ & $0.961 \dagger$ & $1.026 \dagger$ & $\dagger \quad 1.227$ & $* * *$ & 1.347 & $\dagger$ \\
\hline Obs. & 109 & & 109 & & 44 & 44 & 63 & 63 & 56 & 56 & 50 & & 50 & \\
\hline RMSE & 2.347 & & 1.660 & & 2.411 & 0.561 & 2.276 & 2.063 & 1.760 & 1.154 & 2.840 & & 2.107 & \\
\hline $\mathbf{R}^{2}$ & 0.188 & & 0.172 & & 0.245 & 0.363 & 0.160 & 0.135 & 0.182 & 0.228 & 0.221 & & 0.153 & \\
\hline chi2 & 36.680 & & 28.650 & & 18.020 & 26.800 & 20.160 & 13.340 & 21.730 & 20.180 & 19.410 & & 13.170 & \\
\hline \multirow{2}{*}{ (2) Korea } & \multirow{2}{*}{\multicolumn{4}{|c|}{ Overall }} & \multicolumn{4}{|c|}{ By Industry (Note 2) } & \multicolumn{6}{|c|}{ By Scale of Enterprise (Note 3) } \\
\hline & & & & & \multicolumn{2}{|c|}{ Secondary Industry } & \multicolumn{2}{|c|}{ Tertiary Industry } & \multicolumn{2}{|c|}{ Large Enterprises } & \multicolumn{4}{|c|}{ Mid-size Enterprises } \\
\hline (Explained Variable) & S1 & & S2 & & S1 & S2 & S1 & S2 & S1 & S2 & S1 & & S2 & \\
\hline $\begin{array}{l}\text { LN (Regular Male } \\
\text { Employee/Capital) }\end{array}$ & 0.373 & $\dagger$ & -0.051 & ** & $0.125 \dagger$ & $-0.015 *$ & $0.428 \dagger$ & $-0.076^{\star *}$ & $0.347 \dagger$ & 0.001 & 0.331 & $\dagger$ & -0.033 & $* * *$ \\
\hline $\begin{array}{l}\text { LN (Regular Female } \\
\text { Employee/Capital) }\end{array}$ & -0.051 & ** & 0.205 & $\dagger$ & $-0.015 *$ & $0.050 \dagger$ & $-0.076 * *$ & * $0.287 \dagger$ & 0.001 & $0.325 \dagger$ & -0.033 & $* * *$ & 0.092 & $\dagger$ \\
\hline Constant Term & 3.450 & $\dagger$ & 1.917 & $\dagger$ & $1.304 \dagger$ & $0.483 \dagger$ & $3.850 \dagger$ & $2.572 \dagger$ & $3.877 \dagger$ & $3.778 \dagger$ & 3.193 & $\dagger$ & 0.791 & $\dagger$ \\
\hline Obs. & 241 & & 241 & & 118 & 118 & 122 & 122 & 55 & 55 & 186 & & 186 & \\
\hline RMSE & 1.131 & & 0.787 & & 0.388 & 0.138 & 1.479 & 1.060 & 1.536 & 1.212 & 0.891 & & 0.225 & \\
\hline $\mathbf{R}^{2}$ & 0.222 & & 0.175 & & 0.148 & 0.208 & 0.211 & 0.193 & 0.152 & 0.271 & 0.282 & & 0.254 & \\
\hline chi2 & 107.630 & & 94.710 & & 49.370 & 82.250 & 56.270 & 63.100 & 12.470 & 36.810 & 93.180 & & 82.120 & \\
\hline & & & & & & By Industr & ry (Note 2) & & & Scale of $\mathrm{E}$ & Enterprise & $e(N$ & ote 3) & \\
\hline & & & & & Secondar & Iry Industry & Tertiary & y Industry & Large En & nterprises & Mid-si & ize $\mathrm{E}$ & interprise & es \\
\hline (Explained Variable) & S1 & & S2 & & S1 & S2 & S1 & S2 & S1 & S2 & S1 & & S2 & \\
\hline $\begin{array}{l}\text { LN (Regular Male } \\
\text { Employee/Capital) }\end{array}$ & 0.228 & $\dagger$ & -0.011 & $*$ & $0.269 \dagger$ & -0.020 & $0.223 \dagger$ & -0.034 * & $0.172 \dagger$ & $0.032 *$ & 0.248 & $\dagger$ & -0.035 & $*$ \\
\hline $\begin{array}{l}\text { LN (Regular Female } \\
\text { Employee/Capital) }\end{array}$ & -0.011 & * & 0.185 & $\dagger$ & -0.020 & $0.195 \dagger$ & -0.034 * & $0.208 \dagger$ & $0.032 *$ & $0.148 \dagger$ & -0.035 & * & 0.206 & $\dagger$ \\
\hline Constant Term & 1.715 & $\dagger$ & 1.417 & $\dagger$ & $1.914 \dagger$ & $1.433 \dagger$ & $1.543 \dagger$ & $1.419 \dagger$ & $1.607 \dagger$ & $1.446 \dagger$ & 1.709 & $\dagger$ & 1.406 & $\dagger$ \\
\hline Obs. & 282 & & 282 & & 129 & 129 & 153 & 153 & 95 & 95 & 187 & & 187 & \\
\hline RMSE & 0.465 & & 0.393 & & 0.560 & 0.410 & 0.390 & 0.384 & 0.365 & 0.298 & 0.507 & & 0.432 & \\
\hline $\mathbf{R}^{2}$ & 0.300 & & 0.309 & & 0.279 & 0.323 & 0.320 & 0.295 & 0.331 & 0.399 & 0.268 & & 0.268 & \\
\hline chi2 & 196.380 & & 188.410 & & 81.020 & 92.950 & 136.200 & 114.240 & 60.740 & 80.650 & 130.970 & & 117.540 & \\
\hline & & & & & & By Industr & ry (Note 2) & & & Scale of $E$ & Enterprise & $e(N$ & ote 3 ) & \\
\hline & & & & & Secondar & Iry Industry & Tertiary & y Industry & Large En & nterprises & Mid-si & ize E & interprise & \\
\hline
\end{tabular}




\section{Continued}

\begin{tabular}{|c|c|c|c|c|c|c|c|c|c|c|c|c|c|c|c|c|c|c|}
\hline (Explained Variable) & S1 & & S2 & & S1 & & S2 & & S1 & & S2 & & S1 & S2 & S1 & & S2 & \\
\hline $\begin{array}{c}\text { LN (Regular } \\
\text { Employee/Capital) }\end{array}$ & 1.052 & $\dagger$ & -0.324 & $* * *$ & 1.074 & $\dagger$ & -0.126 & & 0.930 & $\dagger$ & -0.320 & ** & $0.910 \dagger$ & $\dagger-0.107$ & 1.828 & $\dagger$ & -1.097 & $\dagger$ \\
\hline $\begin{array}{c}\text { LN (Irregular } \\
\text { Employee/Capital) }\end{array}$ & -0.324 & $* * *$ & 0.453 & $\dagger$ & -0.126 & & 0.270 & $* * *$ & -0.320 & ** & 0.462 & $\dagger$ & -0.107 & 0.324 & $\dagger-1.097$ & $\dagger$ & 1.060 & $\dagger$ \\
\hline Constant Term & 1.336 & $\dagger$ & 1.294 & $\dagger$ & 2.304 & $\dagger$ & 0.995 & $\dagger$ & 0.970 & * & 1.265 & $\dagger$ & $1.941 \dagger$ & $\dagger 1.087$ & $\dagger \quad 0.015$ & & 2.223 & $\dagger$ \\
\hline Obs. & 63 & & 63 & & 25 & & 25 & & 36 & & 36 & & 32 & 32 & 28 & & 28 & \\
\hline RMSE & 3.022 & & 1.299 & & 3.104 & & 0.426 & & 2.828 & & 1.669 & & 2.512 & 0.976 & 3.483 & & 1.549 & \\
\hline $\mathbf{R}^{2}$ & 0.304 & & 0.150 & & 0.416 & & 0.569 & & 0.217 & & 0.108 & & 0.431 & 0.308 & 0.246 & & 0.064 & \\
\hline chi2 & 43.170 & & 23.260 & & 20.460 & & 25.210 & & 25.270 & & 13.980 & & 34.810 & 21.620 & 22.760 & & 14.510 & \\
\hline
\end{tabular}

Data Source: Same as Table 2. Note 1. Based on Equation (4) in this paper, the simultaneous equations for male regular employees $\mathrm{S}_{1}$ and female regular employees S2 were estimated using the SUR model (Seemingly Unrelated Regressions). Expressions of significance are as follows: $\dagger$ : $0.1 \%$; ${ }^{* *}: 1 \%$; ${ }^{* *}: 5 \%$; $10 \%$.Note 2. In the classification of Japanese industries, tertiary industry includes five primary industry enterprises and three foreign investment enterprises whose industry is uncertain. Note 3 . The definitions for scale of enterprise are Table 1, Note 2.

Appendix Table 2. Fundamental Statistics (Substitution and Complementarity Functions).

\begin{tabular}{|c|c|c|c|c|c|c|c|c|c|c|c|c|c|c|c|c|}
\hline \multirow{3}{*}{\multicolumn{2}{|c|}{ Descriptive Statistics }} & \multirow{2}{*}{\multicolumn{3}{|c|}{ Overall }} & \multicolumn{6}{|c|}{ By Industry (Note 2) } & \multicolumn{6}{|c|}{ By Scale of Enterprise (Note 3) } \\
\hline & & & & & \multicolumn{3}{|c|}{ Secondary Industry } & \multicolumn{3}{|c|}{ Tertiary Industry } & \multicolumn{3}{|c|}{ Large Enterprises } & \multicolumn{3}{|c|}{ Mid-size Enterprises } \\
\hline & & 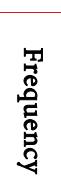 & 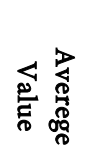 & 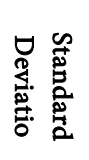 & 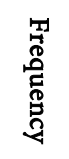 & 究 & 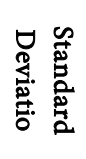 & 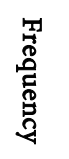 & 究 & 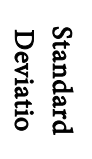 & 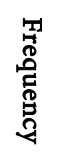 & 蛋 & 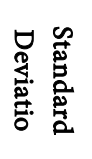 & 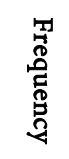 & 蛋 & 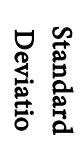 \\
\hline \multirow{6}{*}{ (1) Japan } & S1 (Regular & & & & & & & & & & & & & & & \\
\hline & $\begin{array}{c}\text { Male } \\
\text { Employee) }\end{array}$ & 168 & 1.09 & 3.34 & 65 & 1.10 & 3.96 & 103 & 1.08 & 2.91 & 82 & 1.29 & 4.03 & 86 & 0.90 & 2.53 \\
\hline & $\begin{array}{c}\text { S2 (Regular } \\
\text { Female } \\
\text { Employee) }\end{array}$ & 143 & 0.79 & 2.30 & 53 & 0.31 & 0.70 & 90 & 1.08 & 2.82 & 77 & 0.77 & 2.32 & 66 & 0.82 & 2.29 \\
\hline & $\begin{array}{c}\text { LN (Regular } \\
\text { Male } \\
\text { Employee) }\end{array}$ & 220 & 5.52 & 1.50 & 82 & 5.74 & 1.60 & 138 & 5.39 & 1.43 & 105 & 6.55 & 1.43 & 115 & 4.58 & .77 \\
\hline & $\begin{array}{c}\text { LN (Regular } \\
\text { Female } \\
\text { Employee) }\end{array}$ & 216 & 4.36 & 1.62 & 81 & 4.23 & 1.67 & 135 & 4.43 & 1.59 & 104 & 5.26 & 1.63 & 112 & 3.52 & 1.06 \\
\hline & LN (Capital) & 145 & 5.75 & 3.04 & 59 & 6.55 & 3.25 & 86 & 5.20 & 2.77 & 69 & 6.98 & 3.09 & 76 & 4.63 & 2.53 \\
\hline \multirow[t]{4}{*}{ (2)Korea } & $\begin{array}{l}\text { S1(Regular } \\
\quad \text { Male } \\
\text { Employee) }\end{array}$ & 259 & 0.62 & 1.26 & 127 & 0.31 & 0.53 & 132 & 0.92 & 1.64 & 59 & 0.82 & 1.80 & 200 & 0.56 & 1.05 \\
\hline & $\begin{array}{l}\text { S2 (Regular } \\
\text { Female } \\
\text { Employee) }\end{array}$ & 259 & 0.25 & 0.86 & 127 & 0.07 & 0.16 & 132 & 0.43 & 1.17 & 58 & 0.66 & 1.65 & 201 & 0.13 & 0.34 \\
\hline & $\begin{array}{c}\text { LN (Regular } \\
\text { Male } \\
\text { Employee) }\end{array}$ & 305 & 4.88 & 0.88 & 138 & 5.00 & 0.69 & 167 & 4.79 & 1.01 & 70 & 5.54 & 1.22 & 235 & 4.69 & 0.64 \\
\hline & $\begin{array}{c}\text { LN (Regular } \\
\text { Female } \\
\text { Employee) }\end{array}$ & 305 & 3.60 & 1.41 & 138 & 3.40 & 1.06 & 167 & 3.77 & 1.63 & 70 & 4.86 & 1.48 & 235 & 3.23 & 1.16 \\
\hline
\end{tabular}


Continued

\begin{tabular}{|c|c|c|c|c|c|c|c|c|c|c|c|c|c|c|c|c|}
\hline & LN (Capital) & 276 & 14.00 & 1.82 & 131 & 14.57 & 1.51 & 145 & 13.49 & 1.93 & 62 & 14.77 & 1.76 & 214 & 13.78 & 1.78 \\
\hline \multirow[t]{5}{*}{ (3) China } & $\begin{array}{l}\text { S1 (Regular } \\
\text { Male } \\
\text { Employee) }\end{array}$ & 300 & 0.37 & 0.56 & 137 & 0.41 & 0.66 & 163 & 0.33 & 0.47 & 101 & 0.22 & 0.44 & 199 & .44 & .61 \\
\hline & $\begin{array}{l}\text { S2 (Regular } \\
\text { Female } \\
\text { Employee) }\end{array}$ & 300 & 0.31 & 0.48 & 137 & 0.31 & 0.49 & 163 & 0.31 & 0.46 & 101 & 0.20 & 0.37 & 199 & 0.36 & .51 \\
\hline & $\begin{array}{c}\text { LN (Regular } \\
\text { Male } \\
\text { Employee) }\end{array}$ & 300 & 5.53 & 1.22 & 137 & 5.75 & 1.22 & 163 & 5.34 & 1.19 & 101 & 6.85 & 1.12 & 199 & 4.86 & .51 \\
\hline & $\begin{array}{c}\text { LN (Regular } \\
\text { Female } \\
\text { Employee) }\end{array}$ & 300 & 5.38 & 1.19 & 137 & 5.44 & 1.18 & 163 & 5.33 & 1.20 & 101 & 6.65 & 1.12 & 199 & 4.74 & .52 \\
\hline & LN (Capital) & 300 & 11.77 & 2.13 & 137 & 11.82 & 2.23 & 163 & 11.73 & 2.05 & 101 & 13.57 & 1.83 & 199 & 10.86 & 1.63 \\
\hline \multirow[t]{5}{*}{ (4) Japan } & $\begin{array}{l}\text { S1 (Regular } \\
\text { Employee } \\
\text { (Male and } \\
\text { Female)) }\end{array}$ & 141 & 1.63 & 4.22 & 53 & 1.10 & 2.97 & 88 & 1.95 & 4.80 & 76 & 1.57 & 4.01 & 65 & 1.70 & 4.47 \\
\hline & $\begin{array}{l}\text { S2 (Irregular } \\
\text { Employee } \\
\text { (Male and } \\
\text { Female)) }\end{array}$ & 91 & 0.79 & 2.86 & 32 & 0.27 & 0.59 & 59 & 1.07 & 3.50 & 48 & 0.77 & 3.53 & 43 & 0.81 & 1.88 \\
\hline & $\begin{array}{l}\text { LN (Regular } \\
\text { Employee } \\
\text { (Male and } \\
\text { Female)) }\end{array}$ & 220 & 6.13 & 1.42 & 82 & 6.23 & 1.54 & 138 & 6.07 & 1.34 & 105 & 7.10 & 1.39 & 115 & 5.24 & 0.65 \\
\hline & $\begin{array}{l}\text { LN (Irregular } \\
\text { Employee } \\
\text { (Male and } \\
\text { Female)) }\end{array}$ & 159 & 4.23 & 1.69 & 59 & 4.12 & 1.80 & 100 & 4.30 & 1.63 & 79 & 4.87 & 1.81 & 80 & 3.60 & 1.30 \\
\hline & LN (Capital) & 145 & 5.75 & 3.04 & 59 & 6.55 & 3.25 & 86 & 5.20 & 2.77 & 69 & 6.98 & 3.09 & 76 & 4.63 & 2.53 \\
\hline
\end{tabular}

Data Source: Same as Table 2. Note 1. The author has calculated the cost share value $S$ as average wage $\times$ number of employees $\div$ added value (based on sales). $\mathrm{LN}$ is the value of the natural logarithm. Note 2. In the classification of Japanese industries, tertiary industry includes five primary industry enterprises and three foreign investment enterprises whose industry is uncertain. Note 3. The definitions for scale of enterprise are Table 1, Note2. Note 4. Responses regarding annual wages in Korea were in Scales, as below. The author made the following adaptations to the figures for use in the analysis. Scale 1: less than 20 million won $\rightarrow 18$ million won; scale 2: 20 - 24 million won $\rightarrow 22$ million won; scale 3: 25 - 29 million won $\rightarrow 27$ million won; scale 4: 30 - 34 million won $\rightarrow$ 32 million won; scale 5: 35 - 39 million won $\rightarrow 37$ million won; scale 6: 40 - 44 million won $\rightarrow 42$ million won; scale 7: 45 - 49 million won $\rightarrow 47$ million won; scale 8: 50 - 59 million won $\rightarrow 55$ million won; scale 9: 60 - 69 million won $\rightarrow 65$ million won; scale 10: 70 million won $\rightarrow$ ) taken as 75 million won.

Appendix Table 3. Fundamental Statistics (Wage Function).

\begin{tabular}{|c|c|c|c|c|c|c|c|c|c|c|c|c|c|}
\hline \multirow{3}{*}{$\begin{array}{c}\text { (Variable } \\
\text { Name) }\end{array}$} & \multirow[b]{3}{*}{ (Unit) } & \multicolumn{4}{|c|}{ Japan } & \multicolumn{4}{|c|}{ Korea } & \multicolumn{4}{|c|}{ China } \\
\hline & & \multicolumn{2}{|c|}{ Male } & \multicolumn{2}{|c|}{ Female } & \multicolumn{2}{|c|}{ Male } & \multicolumn{2}{|c|}{ Female } & \multicolumn{2}{|c|}{ Male } & \multicolumn{2}{|c|}{ Female } \\
\hline & & 趂 & 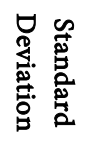 & 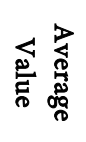 & 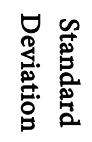 & 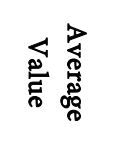 & 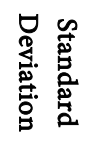 & 兑 & 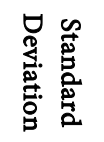 & 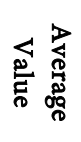 & 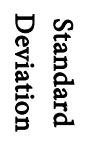 & 蛋 & 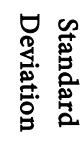 \\
\hline $\begin{array}{l}\text { Hourly Wage } \\
\text { for Regular } \\
\text { Employees }\end{array}$ & $\begin{array}{l}100 \text { yen, } \\
\text { won, } \\
\text { yuan }\end{array}$ & 17.49 & 7.66 & 12.69 & 8.96 & 1538.71 & 528.65 & 1289.98 & 405.76 & 23.47 & 5.60 & 22.07 & 5.01 \\
\hline
\end{tabular}




\section{Continued}

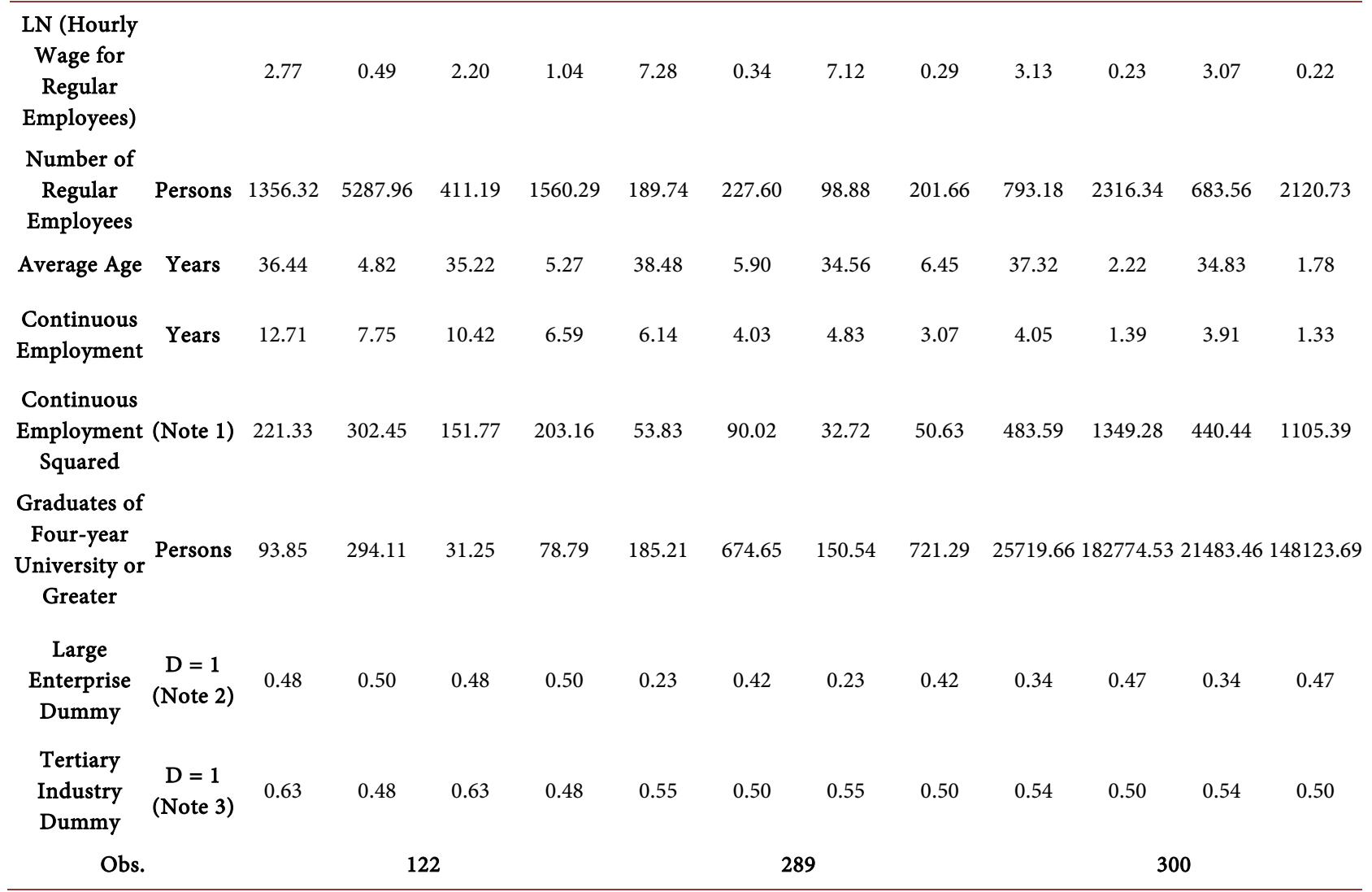

Data Source: Same as Table 2. Note 1. For China only, the number of persons on urban family registers. Note 2 . The definitions for scale of enterprise are Table 1, Note2. Note 3. In the classification of Japanese industries, tertiary industry includes five primary industry enterprises and three foreign investment enterprises whose industry is uncertain. Note 4 . Hourly wage in Korea is the value calculated in Note 4 of Appendix Table 2 divided by average yearly hours of employment. 